\title{
Effects of root dehydration on biomechanical properties of woody roots of Ulex europaeus
}

\author{
D. Boldrin • Anthony K. Leung (iD) A. G. Bengough
}

Received: 20 January 2018 / Accepted: 23 July 2018 / Published online: 10 August 2018

(C) The Author(s) 2018

\begin{abstract}
Aims Effects of root water status on root tensile strength and Young's modulus were studied in relation to root reinforcement of slopes.

Methods Biomechanical properties of woody roots, Ulex europaeus, were tested during progressive dehydration and after thirty-day moisture equilibration in soil with contrasting water contents. Root diameter, water content and water loss were recorded and root water potential versus water content relation was investigated. Tensile stresses induced by root contraction upon dehydration were measured.

Results Root tensile strength and Young's modulus increased abruptly when root water content dropped below $0.5 \mathrm{~g} \mathrm{~g}^{-1}$. The strength increase was due to root radial and axial contraction induced by root water potential
\end{abstract}

Responsible Editor: Antony Van der Ent

Electronic supplementary material The online version of this article (https://doi.org/10.1007/s11104-018-3766-7) contains supplementary material, which is available to authorized users.

D. Boldrin · A. K. Leung · A. G. Bengough

School of Science and Engineering, University of Dundee,

Dundee DD1 4HN, UK

D. Boldrin · A. G. Bengough

The James Hutton Institute, Invergowrie, Dundee DD2 5DA, UK

A. K. Leung $(\bowtie)$

Department of Civil and Environmental Engineering, Hong Kong University of Science and Technology, Clear Water Bay, Sai

Kung, Hong Kong

e-mail: ceanthony@ust.hk drop. Diameter decrease and strength gain were the largest for thin roots because of the relatively larger evaporative surface per volume of thin roots. Largely negative water potentials in dry soil induced root drying, affecting root biomechanical properties.

Conclusion Root water status is a factor that can cause (inappropriately) high strength values and the large variability reported in literature for thin roots. Therefore, all root diameter classes should have consistent moisture for fair comparison. Testing fully hydrated roots should be the routine protocol, given that slope instability occurs after heavy rainfall.

Keywords Eco-engineering $\cdot$ Root dehydration $\cdot$ Root shrinkage $\cdot$ Root water potential $\cdot$ Tensile strength . Young's modulus

\section{Introduction}

Several above- and below-ground plant traits have been shown to affect slope stability by root mechanical and hydrologic reinforcement (e.g. root biomechanical properties, root length density, root biomass (Boldrin et al. 2017a; De Baets et al. 2009; Ghestem et al. 2014b; Loades et al. 2010; $\mathrm{Ng}$ et al. 2016 ; Saifuddin and Osman 2014; Stokes et al. 2009; Yildiz et al. 2018)). Root biomechanical properties such as tensile strength and Young's modulus are the most studied traits in soil bio- and eco-engineering, and they are commonly used to quantify plant effects on slope stability (Bischetti et al. 2005; Fan and Su 2008; Mickovski et al. 2009; Loades 
et al. 2013; Mao et al. 2012; Mattia et al. 2005; Schwarz et al. 2010; Stokes et al. 2008; Wu et al. 1979). Relations between root tensile strength $\left(T_{r}\right)$ and root diameter $(d)$ have been reported in almost all studies that are concerned with root mechanical reinforcement (Bischetti et al. 2009; De Baets et al. 2008; Ghestem et al. 2014a; Mao et al. 2012; Stokes et al. 2008). A negative power law has been commonly used to explain the relation for various plant species (Mao et al. 2012):

$T_{r}=\alpha d^{\beta}$

where $\alpha$ and $\beta$ are empirical coefficients that are speciesspecific. $\beta$ is often less than zero, so roots with smaller diameters would have a greater tensile strength. A list of fitting parameters of the strength versus diameter power relation for 81 species is available in Mao et al. (2012). Moreover, Young' modulus versus diameter relation has also been fitted with the negative power law model (Fan and Su 2008; Jotisankasa and Taworn 2016; Mickovski et al. 2009). However, less information is available concerning the relation between Young's modulus versus diameter compared with that between tensile strength and diameter. Negative power law relations have been commonly used in predictive models for estimating the mechanical root reinforcement provided by different plant types and species (Bischetti et al. 2009; Mao et al. 2012; Schwarz et al. 2010). For instance, Mao et al. (2012) estimated root tensile strength and root reinforcement for a heterospecific forest using generic power law relations for woody and herbaceous plants. These generic power law relations were obtained by meta-analysis of literature data. The power law relation between tensile strength and diameter has been mainly explained by changes in root chemical composition as diameter increases (Genet et al. 2005; Zhang et al. 2014). Genet et al. (2005) explained the negative power law of the strength versus diameter relation through the decrease in cellulose as diameter increases. On the contrary, Zhang et al. (2014) suggested that strength decreases following a decrease in the lignin/cellulose ratio as the diameter increases. Boldrin et al. (2017b) challenged the assumption of negative power law between root diameter and both tensile strength and Young's modulus, after tensile testing several woody species showing no negative power law trends. Support for this came from Mao et al. (2018) who tested four tree species and also showed that not all plant species followed the power law. There is yet to be a commonly accepted explanation for the generally assumed negative power relation between root strength and diameter.

A number of recent studies report no or weak power law relation between root biomechanical properties (i.e. strength and Young's modulus) and diameter (Boldrin et al. 2017b; Ghestem et al. 2014a; Hales et al. 2013; Hales and Miniat 2017; Liang et al. 2017; Mao et al. 2018; Meijer et al. 2018). In particular, Boldrin et al. (2017b) reported strength i) increasing; ii) reducing and iii) increasing initially followed by a reduction as diameter increases when woody roots of ten woody species widespread in Europe were tested. Recent studies have shown that root age (Loades et al. 2015), topological order (Mao et al. 2018) and anatomy (e.g. stele area ratio; Mao et al. 2018) can be better parameters than root diameter for explaining variation in root biomechanical properties and some scatter in strength versus diameter relation. Moreover, soil conditions such as soil density (i.e. relevant to mechanical impedance) and waterlogging can also affect root biomechanical properties and their relations with diameter (Loades et al. 2013).

Despite the importance of plant transpiration controlling some aspects of soil drying for slope stability (i.e. hydrologic reinforcement), most existing laboratory studies omit any information about the root water status before, during or after testing. A limited number of studies do however include some information on root water status when testing (Hales et al. 2013; Hales and Miniat 2017; Preti and Giadrossich 2009; Tosi 2007; Yang et al. 2016). Recently, a review of methods for mechanical testing of woody roots by Giadrossich et al. (2017) listed root moisture among the specimen variables in biomechanical testing. Studies such as Tosi (2007) and Preti and Giadrossich (2009) report root water content and the tensile strength values ranging widely (e.g. water content: 13 and $40 \%$ of dry weight) in root samples of Spartium junceum. Biomechanical testing conducted by Hales and Miniat (2017) and Yang et al. (2016) showed a notable increase in root strength as woody roots dry (e.g. relative water content $<60 \%$ ). Moreover, Boldrin et al. (2017b) hypothesised that root diameter reduction due to drying results in a root strength increase, as strength is calculated from empirical measures of force and diameter (see Materials and methods section; Eq. 5). Indeed, root diameter may notably change in response to plant water status change (Carminati et al. 2013; Huck et al. 1970). Moreover, roots of some species (e.g. cacti and geophytes) could 
deform axially due to contraction of the vascular tissues (i.e. root contraction; De La Barrera and Smith 2009). In these species, root contraction may improve plant anchorage and pull the shoot down in the soil (De La Barrera and Smith 2009). Root contraction upon drying and the consequential changes in root biomechanical properties have rarely been studied, especially for woody species that are of interest in soil bio- and ecoengineering application. In particular, the assessment of root axial contraction (i.e. induced tensile stress) could determine if during root shrinkage upon drying mechanically relevant tissues are involved (e.g. fibres and xylem vessels) in addition to the simple volume loss (i.e. turgor loss) of soft tissues (parenchyma tissues) and diameter decrease.

Most studies mainly focus on root tensile strength and omit any information about root Young's modulus, and how root water status affects these properties. Jotisankasa and Taworn (2016) is one of the few studies which shows that roots of live stakes (Jatropha curcas L.) are stronger and stiffer when dry. The same study also proposes a model to capture any effects of root and soil moisture on root cohesion. Although some recent studies have already shown that root drying can result in a root tensile strength increase (Boldrin et al. 2017b; Hales and Miniat 2017; Jotisankasa and Taworn 2016; Yang et al. 2016), no study has attempted to distinguish quantitatively between the calculation effect due to diameter shrinkage (Boldrin et al. 2017b) and potential changes in material properties. Similarly, it has been suggested that roots of both living and dead trees may equilibrate with soil moisture and change in strength (Hales and Miniat 2017; Watson et al. 1997), but data on the relation between soil moisture and both root strength and Young's modulus are rare. Therefore, the direct effect of root water status on biomechanical properties remains poorly understood.

The objective of this study is to investigate the effects of root drying on root biomechanical properties, aiming to answer the following research questions: (i) Do root tensile strength and Young's modulus increase with root drying? (ii): Are variations of root biomechanical properties upon drying associated with (a) calculation effects due to diameter change or (b) changes in material properties? (iii) Do soil water content and soil water potential affect the biomechanical properties of roots permeating the soil? The experiments reported in this study tested these hypotheses using Ulex europaeus roots sampled from mature plants. U. europaeus roots were selected for testing in this study due to its potential ability to act as an "ecological engineer species" on slopes (Boldrin et al. 2018). In particular, U. europaeus has a notable ability to dry soil along a depth profile due to its fast root growth rate and resource use (Boldrin et al. 2018). Thus U. europaeus roots may be often subjected to large soil moisture fluctuations.

\section{Materials and methods}

\section{Root materials}

Ulex europaeus L. (Fabaceae; common name: gorse) is a woody perennial shrub species, native to Europe and North Africa. U. europaeus can grow in nutrient-poor soils (e.g. sand dunes) and generally colonizes highly disturbed areas such as roadsides, over-grazed pastures, logged areas and burnt over forests. In Scotland, U. europaeus is one of the most common woody species on natural and man-made slopes. $U$. europaeus is a suitable species for eco-engineering due to its pioneer nature (Norris et al. 2008) and its ability to provide hydro-mechanical reinforcement (Boldrin et al. 2017a, b; Boldrin et al. 2018; Liang et al. 2017). For instance, Boldrin et al. (2018) found that soil drying by $U$. europaeus induced a soil strength gain (up to sixfold the value at saturation) along the entire depthprofile in 1-m soil columns. U. europaeus was recently chosen by Liang et al. (2017) as a model species to study the effects of root mechanical reinforcement on slope stability in a geotechnical centrifuge. In June 2017, roots of $U$. europaeus were sampled in Scotia Seeds farm, Brechin, UK (East Scotland, 56 69'99' ' N, 265'56" $\mathrm{W})$, from a monospecific hedge constituted by 17 yearold $U$. europaeus plants. Roots were carefully collected from the top $0.3 \mathrm{~m}$ of soil in three different sampling sites along the hedge. To avoid any dehydration of root materials during sampling, root samples were immediately stored in plastic bags with wet blotting tissues. After sampling, roots were washed from the soil using a set of sieves (from 2 to $0.5 \mathrm{~mm}$ mesh) and cut into $150 \mathrm{~mm}$ segments. Only root segments that were free of tortuosity or tissue damages were selected for tensile testing. Root segments with a noticeable departure from cylindrical shape were discarded. Each root segment was fully hydrated in distilled water for $24 \mathrm{~h}$ and then stored at $5^{\circ} \mathrm{C}$ in sealed plastic bags with moist blotting tissues. All roots were tested for their biomechanical 
properties within one week after hydration, unless stated otherwise.

\section{Root drying treatments}

To test the effects of root drying on root biomechanical properties roots were air dried for different periods (i.e. time 0 (hydrated roots), $30 \mathrm{~min}, 1 \mathrm{~h}, 2 \mathrm{~h}, 5 \mathrm{~h}$ and $24 \mathrm{~h}$ drying) in a controlled environment (temperature: 20.00 $\pm 0.02{ }^{\circ} \mathrm{C}$ (mean \pm standard error of mean); relative humidity: $39.35 \pm 0.11 \%$ ). During air-drying, all root segments were placed on plastic flat trays. For each treatment, $\approx 40$ segments were prepared.

During drying no additional heating was provided so roots lost their water content through natural evaporation. Initially, the hydrated diameter (i.e. initial diameter before treatment) of selected root segments was measured at three marked points along each root axis using a stereo microscope and graticule (Leica, Milton Keynes, United Kingdom) for roots thinner than $3 \mathrm{~mm}$ and digital caliper for larger roots. The three measuring points were located in the middle of the segment and at approximately $25 \mathrm{~mm}$ from both segment ends (i.e. at 25; 75 and $125 \mathrm{~mm}$ along the root segment). The standard deviation among the three measurements had a median value of $0.12(n=585$, all root segments tested). Following diameter measurement, root segments were evenly and randomly distributed in the different treatments, ensuring that each diameter class was represented in each treatment. Root water loss $\left(\mathrm{W}_{\mathrm{L}} ; \mathrm{g} \mathrm{g}^{-1}\right)$ for each segment was determined using Eq. (2):

$W_{L}=\frac{\mathrm{M}_{\text {hyd }}-\mathrm{M}_{t}}{\mathrm{M}_{\text {hyd }}}$

where $\mathrm{M}_{\text {hyd }}$ and $\mathrm{M}_{t}$ are the weight ( $\mathrm{g}$ ) of the hydrated root segment before treatment (i.e. time 0 ) and its weight after treatment (i.e. after drying time-lapses), respectively. Samples were weighed on an electronic 3-decimalplace balance. To avoid further water loss after the drying stage, each root segment that was ready to be mechanically tested was wrapped in a plastic film, sealed in a plastic bag and kept in a polystyrene box with ice packs before testing. After treatment (i.e. drying), all root segments were tested for their biomechanical properties within $30 \mathrm{~min}$. Prior to each biomechanical test, root water content $\left(\mathrm{W}_{\mathrm{C}} ; \mathrm{g} \mathrm{g}^{-1}\right)$ was measured on a sub-section $(25-30 \mathrm{~mm}$ ) for each root segment by oven-drying (Eq. 3):
$W_{C}=\frac{\mathrm{M}_{f}-\mathrm{M}_{d}}{\mathrm{M}_{d}}$

where $\mathrm{M}_{f}$ and $\mathrm{M}_{d}$ are the weight (g) of the fresh root sub-section and its oven-dry weight, respectively. Ovendry weight of the sub-section was obtained by drying the material at $70{ }^{\circ} \mathrm{C}$ until a constant weight was recorded. Samples were weighed on an electronic 4-decimal-place balance. Note that water content per dry weight $\left(\mathrm{g} \mathrm{g}^{-1}\right)$ can be transformed in percentage water content per fresh weight using Eq. (4).

$W_{C} \%=\left(\frac{\mathrm{W}_{C}}{\mathrm{~W}_{C}+1}\right) * 100$

Diameter of root segments, after drying treatments and immediately before biomechanical testing (i.e. final diameter), was again measured at the three marked points used for the initial diameter measurement on hydrated root segments.

\section{Biomechanical properties of roots}

Root tensile tests were performed to assess the biomechanical properties (i.e. tensile strength and Young's modulus) of the root segments using a universal testing frame (Instron 5966, Norwood, MA, USA) at an extension rate of $2 \mathrm{~mm} \mathrm{~min}^{-1}$. A typical duration for a tensile test was approximately four minutes (e.g. $3.93 \pm$ $0.11 \mathrm{~min}$ for hydrated roots in the diameter range between 0.5 and $5.6 \mathrm{~mm}$ ). However, the duration of a tensile test could vary among samples due to the inherent variability of biological materials and root biomechanical properties. Tensile tests were carried out using $50 \mathrm{~N}, 500 \mathrm{~N}$ and $2 \mathrm{kN}$ load cells, depending on the range of the root diameters being tested. To avoid slippage of roots in the clamps, both manually-tightened and pneumatic clamps were used, again depending on the root diameter. Pneumatic clamps with pressures ranging from 100 to $250 \mathrm{kPa}$ were used for roots larger than $2 \mathrm{~mm}$ in diameter. The length of the root section between clamps was $60 \mathrm{~mm}$. The tensile strength (MPa) and Young's modulus (MPa) of each root section were determined from the corresponding stress-strain curve (De Baets et al. 2008; Loades et al. 2013). Tensile strength $\left(T_{r}\right)$ was obtained using Eq. (5):

$$
T_{r}=\frac{F}{\pi\left(\frac{d^{2}}{4}\right)}
$$


where $F$ is the peak force required to break a root $(\mathrm{N})$ and $d$ is the root diameter (mm). Note that in the present study, tensile strength was calculated using both initial (i.e. hydrated root before treatment) and final (i.e. after treatment) diameters. The use of initial or final diameter, in the tensile strength calculation, is stated explicitly in the Results section. The diameter decrease $(\Delta d)$ due to shrinkage as root dries was calculated using Eq. (6):

$\Delta d=\left(\frac{\mathrm{d}_{i}-\mathrm{d}_{f}}{\mathrm{~d}_{i}}\right) * 100$

where $\mathrm{d}_{i}$ and $\mathrm{d}_{f}$ are the initial and final diameter (i.e. after treatment) of the root segment, respectively. Therefore the diameter decrease can be expressed as relative diameter, which is equal to Eq. (7):

$\% d_{f} / d_{i}=\left(\frac{\mathrm{d}_{f}}{\mathrm{~d}_{i}}\right) * 100$

Any change in tensile strength $\left(\Delta T_{r} ; \%\right)$ due to diameter change by root drying and shrinkage was calculated using Eq. (8):

$\Delta T_{r}=\left(\frac{\left(T_{\mathrm{fd}}-T_{\mathrm{id}}\right)}{T_{\mathrm{id}}}\right) * 100$

where $T_{\mathrm{fd}}$ and $T_{\mathrm{id}}$ are the tensile strength calculated using final (i.e. after treatment) and initial (i.e. hydrated root before treatment) diameter, respectively.

Young's modulus $\left(E_{r}\right)$ was derived from the initial gradient of the tensile stress-strain curve within the elastic region (i.e. initial linear part):

$E_{r}=\frac{F L_{O}}{\pi\left(\frac{d^{2}}{4}\right) \Delta L}$

where $F$ is the applied force $(\mathrm{N}) ; L_{o}$ is the initial length (mm) of the root sample; and $\Delta L$ is the change in root length $(\mathrm{mm})$ during tensioning. Young's modulus was calculated using the final diameter, measured immediately before testing (i.e. after drying/treatment), unless stated otherwise. Note that the initial root length between clamps was $60 \mathrm{~mm}$.

The ratio between surface area $\left(\mathrm{mm}^{2}\right)$ and volume $\left(\mathrm{mm}^{3}\right)$ of each root segment was calculated from the initial diameter (i.e. hydrated diameter before treatment) and the segment length $\left(L_{s} ; 150 \mathrm{~mm}\right)$, assuming a cylindrical shape:
$\frac{A}{V}=\frac{\pi d L_{s}+\left(\pi(d / 2)^{2}\right) * 2}{\pi(d / 2)^{2} L_{s}}$

Biomechanical properties of roots in soil with different water contents

To evaluate the effect of soil water content on the biomechanical properties of roots buried in soil, four contrasting soil water contents (i.e. treatments) were tested. The soil used in this study was collected from Bullionfield, The James Hutton Institute, Dundee, UK. It was a sandy loam (71\% sand, $19 \%$ silt and $10 \%$ clay (Loades et al. 2013)). The initial water content $\left(\mathrm{g} \mathrm{g}^{-1}\right)$ of soil (sieved $<4 \mathrm{~mm}$ ) was measured by oven-drying three soil sub-samples at $105^{\circ} \mathrm{C}$ for $72 \mathrm{~h}$. Subsequently, water was added to the soil to achieve different target water contents: $0.09,0.15$ and $0.25 \mathrm{~g} \mathrm{~g}^{-1}$ (i.e. soil treatments). After adding the desired amount of water, the soil was left to equilibrate in sealed plastic bags for $72 \mathrm{~h}$. After equilibration, soil water content was measured again to verify if the target water contents were achieved. Dry soil was obtained by oven-drying the soil for $72 \mathrm{~h}$ at $105^{\circ} \mathrm{C}$.

Root segments (150 mm length) were fully hydrated for $24 \mathrm{~h}$ in distilled water at $5^{\circ} \mathrm{C}$. Then, 112 roots were tested for their water content (Eq. 3) and biomechanical properties (i.e. tensile strength and Young's modulus), as control (i.e. fully hydrated roots). After diameter (i.e. initial diameter) measurements, the remaining root segments were labelled, enclosed in polyester net bags $(<$ $0.2 \mathrm{~mm}$ mesh aperture) and buried in soil pre-equilibrated at the target water contents. Soils with roots were kept in sealed bags inside polystyrene boxes to avoid water loss and thermal fluctuation (temperature: $20^{\circ} \mathrm{C}$ ). Roots were evenly and randomly attributed to each treatment, ensuring that each diameter class was represented $(\approx 55 \mathrm{seg}$ ments per treatment). After 30 days, all root segments were extracted from soil and tested for water content and biomechanical properties. The final soil water content and water potential $(\mathrm{MPa})$ were measured. Soil water potential was measured on three samples per each treatment (i.e. soil water content) using a dew-point hygrometer (WP4-T, Decagon Devices).

\section{Root water release curve}

The relation between root water content $\left(\mathrm{g} \mathrm{g}^{-1}\right)$ and water potential $(\mathrm{MPa})$, representing the root water release curve, was obtained from four replicate root 
segments. Fully hydrated root segments $(20-30 \mathrm{~mm}$ length; $2.8-4.1 \mathrm{~mm}$ diameter) were placed in sampling holders (diameter $40 \mathrm{~mm}$; height $10 \mathrm{~mm}$ ) to measure their water potential using a dew-point hygrometer (WP4-T, Decagon Devices). Samples were then immediately weighed on an electronic 4-decimal-place balance. The root water potential and root weight were measured at frequent intervals during progressive dehydration until the water potential reached $-7 \mathrm{MPa}$. Finally, root samples were oven-dried at $70{ }^{\circ} \mathrm{C}$ until a constant weight was recorded. Water content during progressive dehydration was calculated using Eq. (3).

\section{Root contraction stress induced by drying}

To investigate any change in root strength due to root drying, the stress (i.e. force per cross-section area of root) induced by root axial shrinkage was measured using the universal testing frame (Instron 5966). An individual root segment (150 mm length; $1.4-2.2 \mathrm{~mm}$ diameter) was clamped using manually-tightened clamps with a $500 \mathrm{~N}$ load cell (root length between clamps $=60 \mathrm{~mm}$ ). Initially, each root segment was stretched with $5 \mathrm{~mm} \mathrm{~min}^{-1}$ extension rate until $1 \mathrm{MPa}$ of root tensile stress was reached. An initial stress of $1 \mathrm{MPa}$ was imposed to stretch the root material and allow subsequent recording of root contraction. Tensile stress of $1 \mathrm{MPa}$ corresponded to $\approx 6 \%$ of peak tensile strength (i.e. tensile strength at maximum load; shown later) and fell within the elastic region of the stress-strain curve of $U$. europaeus roots. Subsequently, each root sample was held (i.e. displacement unchanged) and any tensile stress, induced by root contraction upon drying, was recorded for $72 \mathrm{~h}$ continuously to obtain a tensile stress versus time plot. At the end of each test (i.e. after $72 \mathrm{~h}$ ), tensile strength at maximum load and Young' modulus of root segments were tested with an extension rate of $2 \mathrm{~mm} \mathrm{~min}^{-1}$. In the calculation of tensile strength and Young's modulus, the initial diameter of hydrated root segment (i.e. time 0 right before testing) was used. Initial and final (i.e. after $72 \mathrm{~h}$ ) water content were measured on sub-sections of tested root segments. A root sub-section for the measurement of initial water content was cut from each root segment before testing. Immediately after testing, a root sub-section was removed from the tested root for final water content measurement. Ten additional roots were tested for $24 \mathrm{~h}$ to assess the effects of a shorter drying period. During the study, laboratory temperature and relative humidity averaged $22.0 \pm 0.0{ }^{\circ} \mathrm{C}$ and $54.3 \pm 0.1 \%$ (recorded at 30 min intervals; July - August 2017), respectively.

Statistical analysis

Statistical analysis was performed using GenStat 17th Edition (VSN International) and SigmaPlot13 (Systat Software Inc). Significant differences were assessed with one way-ANOVA, followed by post hoc Tukey's test. Data that did not follow a normal distribution were $\log$ or square root transformed before ANOVA. Wilcoxon Matched-Pairs test was used to compare before-and-after treatment observations on the same samples (for non-normally distributed data, e.g. diameter before-and-after 30 days in dry soil). Logtransformed tensile strength and Young's modulus were analysed using Generalized Linear Models (GLM) with normal distribution and identity link function. Root water content and final diameter (i.e. after treatment) were included as fixed factors to assess their effect on biomechanical properties and interactions. GLM with normal distribution and identity link function were also used to test the effect of initial diameter and treatment on tensile strength change due to diameter change (logtransformed data). Results were considered statistically significant when $p$-value $\leq 0.05$. The variability of averaged data is expressed as \pm standard error of mean.

\section{Results}

Biomechanical properties of roots

Root stress-strain curves of hydrated roots showed the typical biphasic nature with both elastic and plastic behaviour (Fig. 1; Loades et al. 2013; Yang et al. 2016). Evidently, the drying treatment affected the stress-strain curve of the tested roots. For instance, drier roots (e.g. $24 \mathrm{~h}$ drying treatment) showed a much stiffer response and were more brittle (i.e. break at small strain), compared with hydrated root samples (Fig. 1). In contrast, hydrated roots underwent greater elongation (e.g. > 10\% strain) and were thus more ductile, broke at relatively large strain well beyond their elastic limit (i.e. large plastic region). The hydrated roots of $U$. europaeus (Fig. 2a, g) showed maximum tensile strength and Young's modulus values up to $30.7 \mathrm{MPa}$ (mean = 16.0 $\pm 0.9 \mathrm{MPa}$ ) and $852.0 \mathrm{MPa}$ $($ mean $=425.6 \pm 29.5 \mathrm{MPa})$, respectively. Both biomechanical properties showed no relation with diameter 
recorded immediately before testing (i.e. after treatment), apparently remaining constant with root diameter from 0.55 to $6.19 \mathrm{~mm}$. Moreover, the greatest tensile strength (30.7 MPa) was recorded in a thick root (i.e. $3.93 \mathrm{~mm}$ ). The relation between diameter and strength started to change after $2 \mathrm{~h}$ (Fig. $2 \mathrm{~d}$ ), when a tensile strength value up to $48.0 \mathrm{MPa}$ was recorded in a thin root $(0.50 \mathrm{~mm})$. Subsequently, after 5 and $24 \mathrm{~h}$ (Figs 2e, f), the increase in the strength of thin roots (i.e. $<2 \mathrm{~mm}$ ) became more evident, highlighting a negative power-law relation between root diameter and tensile strength. Indeed, after $24 \mathrm{~h}$, the average strength of thin roots $(40.0 \pm 5.3 \mathrm{MPa})$ was twice as large as that in thicker roots ( $>2 \mathrm{~mm} ; 20.5 \pm$ 2.6 $\mathrm{MPa})$. Moreover, the greatest strength value $(118.3 \mathrm{MPa})$, recorded after $24 \mathrm{~h}$, was four times larger than that recorded in hydrated roots. Young's modulus versus diameter relation exhibited an abrupt change after $24 \mathrm{~h}$, when Young's modulus of thin roots increased up to 5051.6 MPa (Fig. 21). In this case, Young's modulus versus diameter relation could also be fitted by a negative power law relation.

\section{Root water loss and root water content}

Root water loss increased with time (Fig. 3) with a strong diameter-dependent relation. Thin roots $(<$ $2 \mathrm{~mm}$ ) lost more water than thicker roots (Figs 3a, b and c). Indeed, after only $30 \mathrm{~min}$ of drying, thin roots lost up to $24 \%$ of their initial weight. On the contrary, roots larger than $2 \mathrm{~mm}$ showed an evident water loss only after $5 \mathrm{~h}$ drying. The relation between water loss

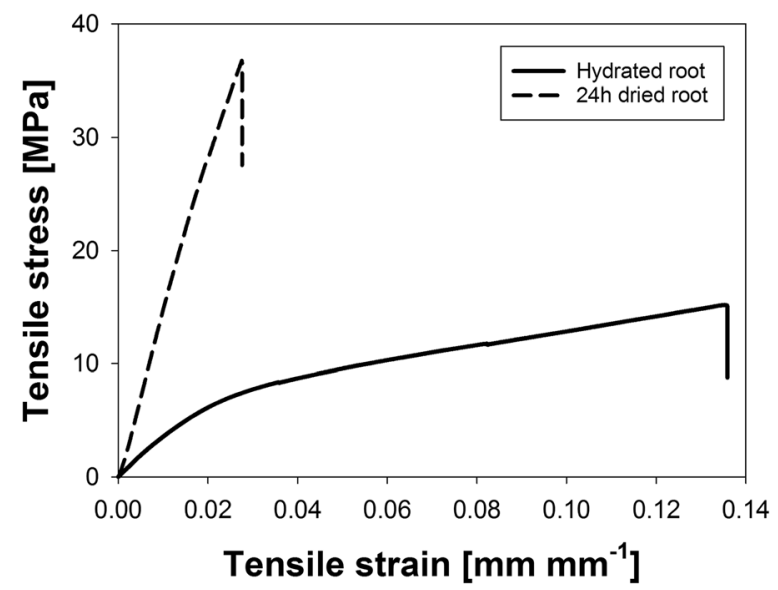

Fig. 1 Typical tensile stress versus tensile strain curves for a hydrated root sample $\left(d=1.48 \mathrm{~mm} ; w=1.89 \mathrm{~g} \mathrm{~g}^{-1}\right)$ and a root sample air-dried for $24 \mathrm{~h}(d=1 \mathrm{~mm}$ (before drying $1.40 \mathrm{~mm}$ ); $w=0.11 \mathrm{~g} \mathrm{~g}^{-1}$ ) and diameter (initial) could be described by a negative power law explaining about $90 \%$ of the variability (Figs $3 \mathrm{a}, \mathrm{b}, \mathrm{c}$ and d; Table 1). This relation became linear after $24 \mathrm{~h}$ drying when thick roots showed a notable water loss (Fig. 3e). Root water content versus diameter relations showed opposite trends with water loss versus diameter relations, as expected (Fig. 3). At time 0 (i.e. fully-hydrated roots), water content ranged between 1.37 and $2.73 \mathrm{~g} \mathrm{~g}^{-1}$, recorded in 4.09 and $0.75 \mathrm{~mm}$ diameter roots, respectively (Fig. $3 \mathrm{f}$ ). Thin roots highlighted a progressive dehydration with large roots maintaining greater water content for longer. Indeed, the water content of large roots did not drop below $0.95 \mathrm{~g} \mathrm{~g}^{-1}$ even after $5 \mathrm{~h}$ drying whereas thin roots showed a minimum value of $0.11 \mathrm{~g} \mathrm{~g}^{-1}$ (Fig. 3j). After $24 \mathrm{~h}$ drying, root water content highlighted a linear and positive relation with initial diameter (Fig. $3 \mathrm{k}$ ).

Water loss was positively correlated with the root area/ volume ratio (A/V; Fig. 4; Table 2). In particular, water loss was linearly related to root area/volume ratio in all treatments except that recorded after $24 \mathrm{~h}$ drying, where the relation was logarithmic. Root area/volume ratio was the highest in thin roots but quickly decreased as root diameter increased, following a negative power law.

\section{Effects of root water status on root biomechanical} properties

Both root tensile strength and Young's modulus showed a power law relation with root water content (Fig. 5; Table 3). In particular, abrupt increases in both root strength and Young's modulus were observed when root water content dropped below $0.5 \mathrm{~g} \mathrm{~g}^{-1}$. Water content could explain more than $40 \%$ of the variability in Young' modulus (Table 3 ). Tensile strength was significantly affected by water content ( $p$-value $<0.001)$ and diameter $(p$-value $=0.029)$ when all treatments were considered in the GLM analysis. Similarly, Young's modulus was significantly affected by water content $(p$-value $<0.001)$, diameter $(p$-value $=0.046)$ and the water content-diameter interaction ( $p$-value $<0.001)$.

Roots subjected to progressive dehydration (i.e. water loss) showed a large decrease in diameter (Fig. 6 and Suppl. Fig. 1) with root segments shrinking by $30 \%$ with respect to the initial diameter, when water loss increased to $0.7 \mathrm{~g} \mathrm{~g}^{-1}$. Therefore, tensile strength, calculated from the initial diameter (i.e. before treatment), could substantially differ from that obtained using the final diameter (i.e. after treatment; Fig. 7; Table 4). Indeed, 


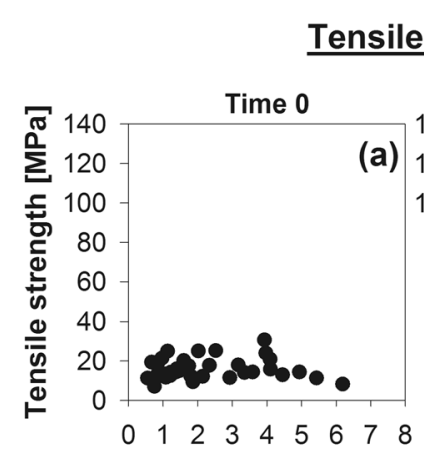

Tensile strength
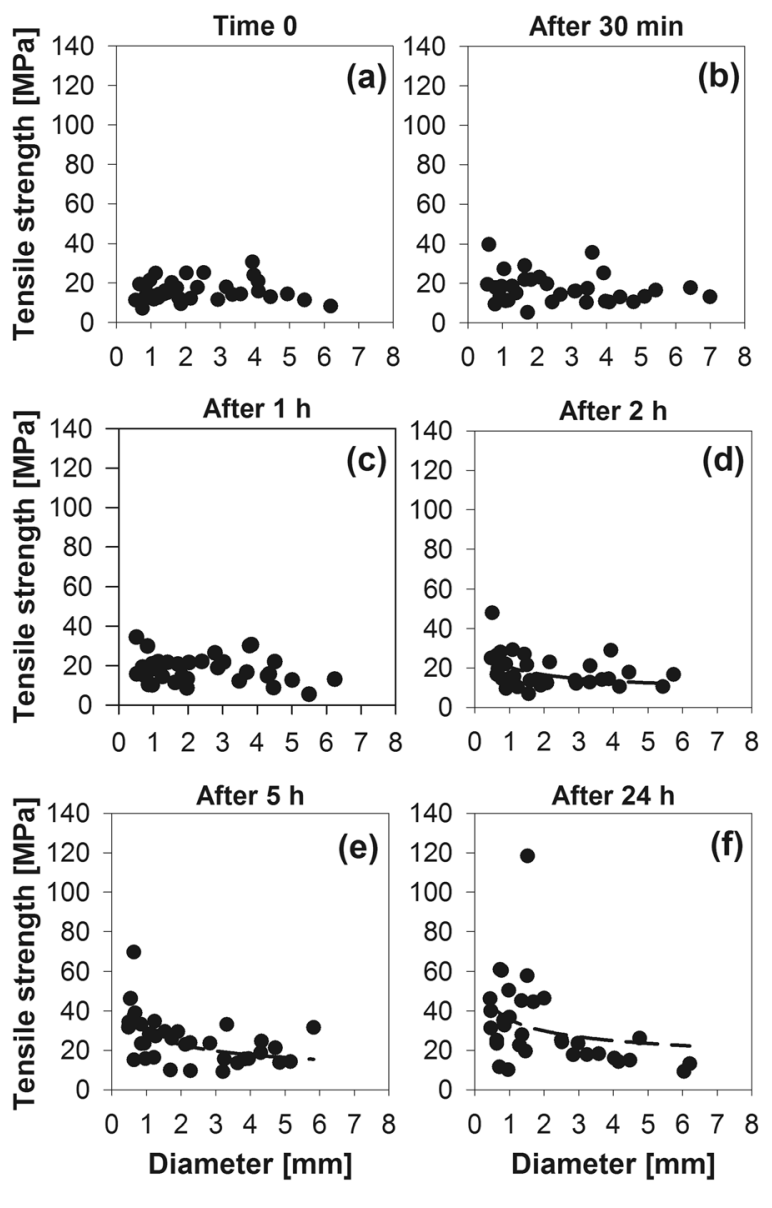

Fig. 2 Root biomechanical properties plotted against final diameter (i.e. after treatment). Tensile strength versus diameter relation for (a) fully hydrated roots at time $0, n=36$; (b) After $30 \mathrm{~min}$ drying, $n=33$; (c) After $1 \mathrm{~h}$ drying, $n=35$; (d) After $2 \mathrm{~h}$ drying, $\mathrm{n}=33\left[T_{r}=20.43 * d^{0.31} ; \mathrm{R}^{2}=0.18\right] ;$ (e) After 5 h drying, $\mathrm{n}=36$ $\left[T_{r}=29.32 * d^{-0.37} ; \mathrm{R}^{2}=0.32\right] ;$ (f) After $24 \mathrm{~h}$ drying, $\mathrm{n}=33\left[T_{r}=\right.$

after $5 \mathrm{~h}$ drying, the root tensile strength obtained by using root final diameter was significantly different ( $p$-value of Wilcoxon Matched-Pairs test $<0.001)$ from the one calculated with initial diameter. The percentage change in tensile strength due to diameter change $\left(\Delta T_{r}\right)$ was significantly affected by initial root diameter $(p$-value $<0.001)$ and treatment ( $p$-value $<0.001$ ), as well as by their interaction ( $p$-value $<0.001$ ). Indeed, $\Delta T_{r}$ versus initial diameter relation highlighted negative power trends after $2 \mathrm{~h}$ drying (Fig. 7c, d and e). Thin roots showed a notable decrease in diameter and hence increase in calculated strength (Fig. 7). In contrast, larger roots highlighted minor changes in diameter and hence no or minor tensile
Young's modulus
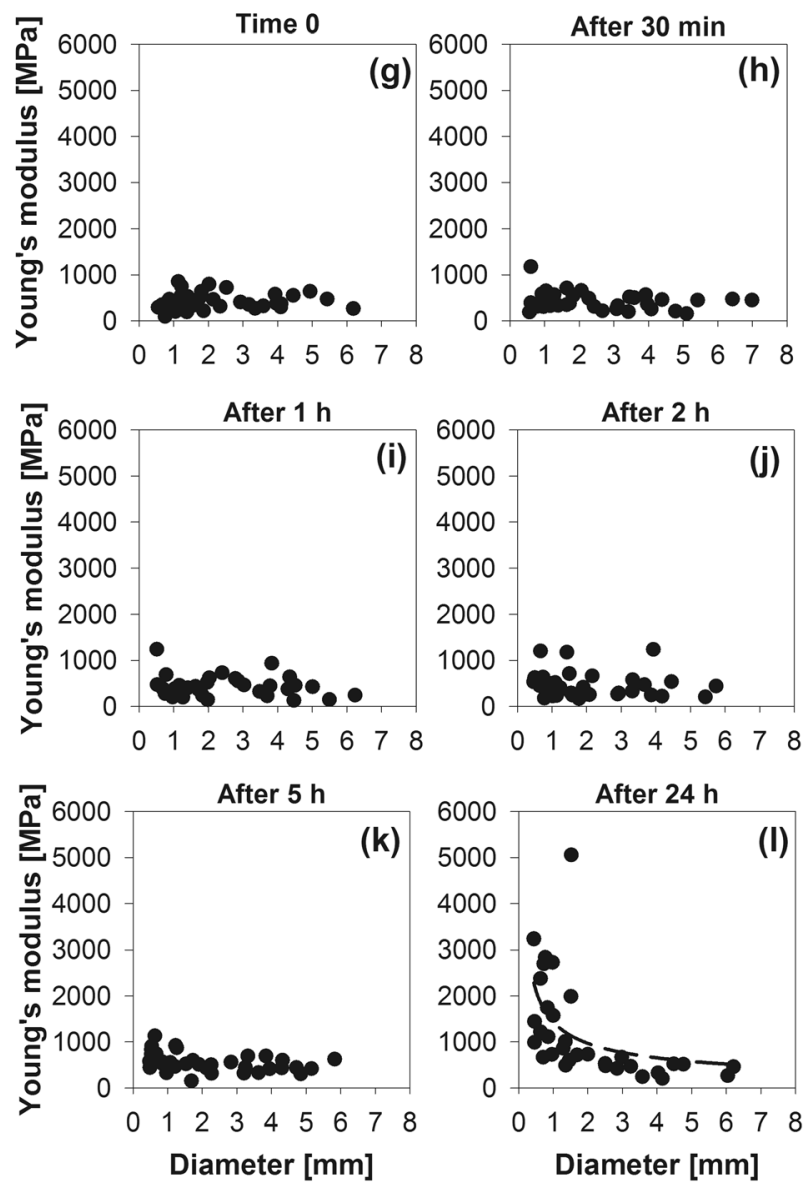

$\left.35.62 * d^{-0.26} ; \mathrm{R}^{2}=0.08\right]$. Young's modulus versus diameter relation for (g) fully hydrated roots at time $0, \mathrm{n}=36$ (h) After $30 \mathrm{~min}$ drying, $\mathrm{n}=33$; (i) After $1 \mathrm{~h}$ drying, $\mathrm{n}=35$; (j) After $2 \mathrm{~h}$ drying, $\mathrm{n}=$ 33; (k) After $5 \mathrm{~h}$ drying, $\mathrm{n}=36$; (l) After $24 \mathrm{~h}$ drying, $\mathrm{n}=33$ [ $E_{r}=$ $\left.1432.88 * d^{0.57} ; \mathrm{R}^{2}=0.24\right]$. Dashed lines represent best fitted curves

strength change (Fig. 7). After $5 \mathrm{~h}$ drying, tensile strength in thin roots $(<2 \mathrm{~mm})$ increased by up to $162 \%$, while in larger roots the increase was less than $30 \% . \Delta T_{r}$ was positively correlated with root water loss (Fig. 8), as expected. For instance, $100 \% \Delta T_{r}$ was associated with root water loss ranging between 0.5 and $0.7 \mathrm{~g} \mathrm{~g}^{-1}$.

Effects of soil water content on root biomechanical properties

After 30 days moisture equilibration between root and soil, soil water content showed a small reduction in $0.25 \mathrm{~g} \mathrm{~g}^{-1}$ soil treatment (i.e. $0.23 \mathrm{~g} \mathrm{~g}^{-1}$ ) and a little 


\section{Root water loss}
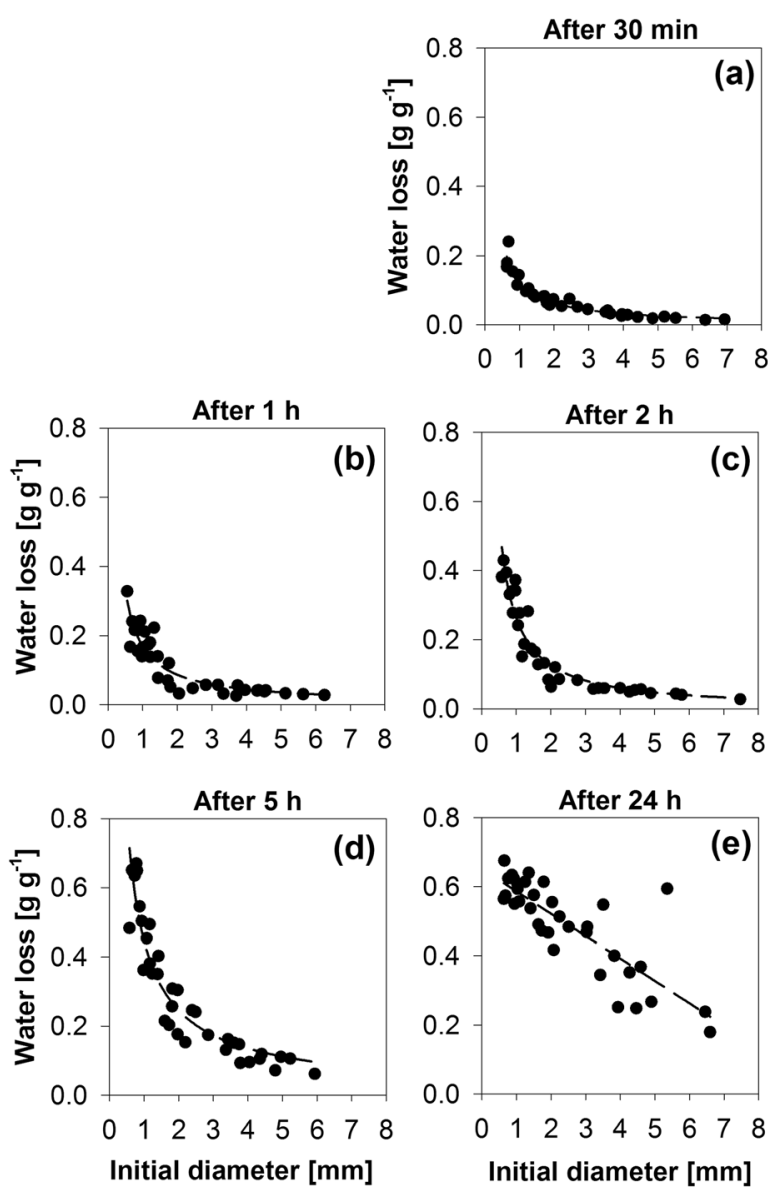

Fig. 3 Root water loss and water content plotted against initial diameter (diameter of hydrated roots before treatments). Root water loss - diameter relation for after (a) $30 \mathrm{~min}$; (b) $1 \mathrm{~h}$; (c) $2 \mathrm{~h}$; (d) $5 \mathrm{~h}$; (e) $24 \mathrm{~h}$ drying. Root water content - diameter relation for (f) fully hydrated roots at time 0 ; (g) after $30 \mathrm{~min}$; (h) $1 \mathrm{~h}$; (i)

\section{Root water content}
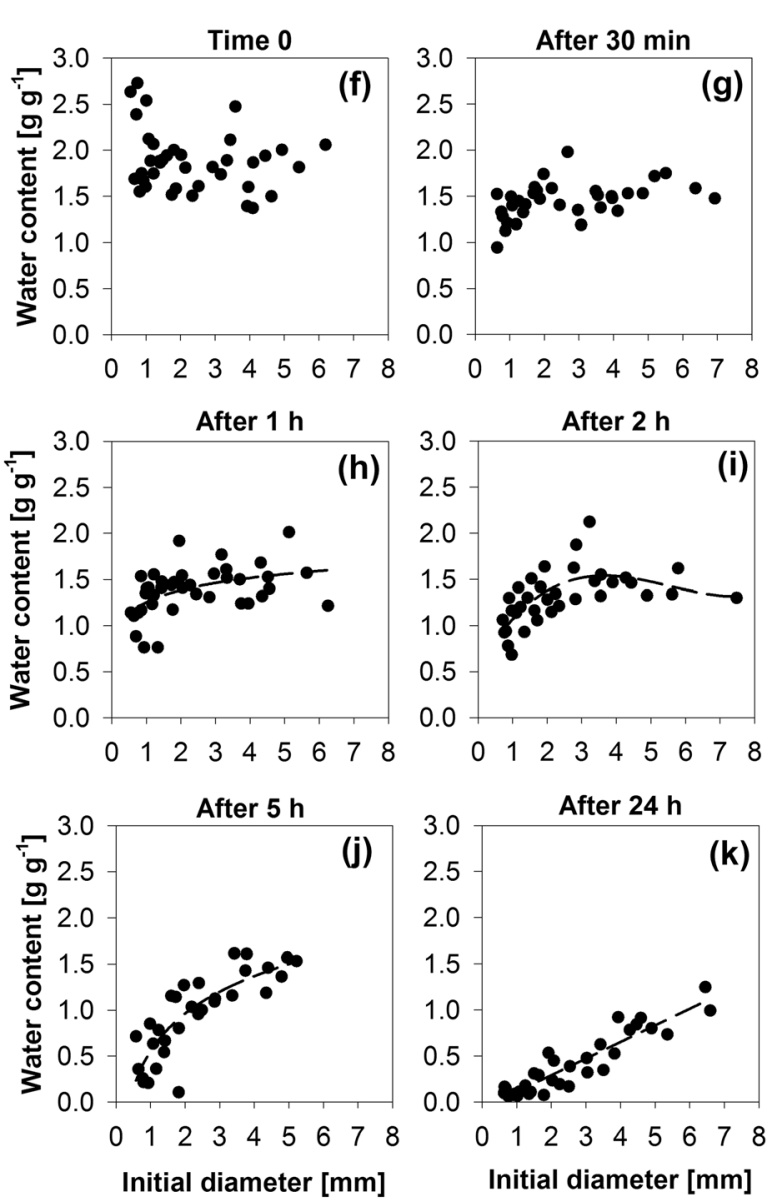

$2 \mathrm{~h}$; (j) $5 \mathrm{~h}$; (k) $24 \mathrm{~h}$ drying. Water loss is defined as g of water loss per g of root fresh weight (hydrated root). Water content is defined as $g$ of water per $g$ of dry root material. Dashed lines represent best-fitted curves. Best-fit equations and the corresponding $\mathrm{R}^{2}$ are given in Table 1

Table 1 Summary of best-fit equations, $\mathrm{R}^{2}$ and number of samples (n) for the relations between initial root diameter $\left(d_{i}\right)$, root water loss $\left(W_{L}\right)$ and root water content $\left(W_{C}\right)$ in different treatments (Fig. 3)

\begin{tabular}{|c|c|c|c|c|c|c|}
\hline & Root water loss & & & Root water content & & \\
\hline Treatment & $\mathrm{Eq}$ & $\mathrm{R}^{2}$ & $\mathrm{n}$ & $\mathrm{Eq}$ & $\mathrm{R}^{2}$ & $\mathrm{n}$ \\
\hline Time 0 & - & - & - & - & - & 38 \\
\hline After $30 \mathrm{~min}$ & $W_{L}=0.13 * d_{i}^{-0.99}$ & 0.93 & 31 & - & - & 35 \\
\hline After $1 \mathrm{~h}$ & $W_{L}=0.17 * d_{i}^{-0.97}$ & 0.83 & 35 & $W_{C}=1.26+0.19 * \ln \left(d_{i}\right)$ & 0.22 & 39 \\
\hline After $2 \mathrm{~h}$ & $W_{L}=0.26^{*} d_{i}^{-1.07}$ & 0.90 & 33 & $W_{C}=0.53+0.66 * d_{i}-0.14 * d_{i}{ }^{2}+0.01 * d_{i}{ }^{3}$ & 0.43 & 36 \\
\hline After $5 \mathrm{~h}$ & $W_{L}=0.45^{*} d_{i}^{-0.86}$ & 0.88 & 37 & $W_{C}=0.56+0.59 * \ln \left(d_{i}\right)$ & 0.68 & 31 \\
\hline After $24 \mathrm{~h}$ & $W_{L}=0.65-0.06 * d_{i}$ & 0.66 & 35 & $W_{C}=-0.07+0.18 * d_{i}$ & 0.86 & 35 \\
\hline
\end{tabular}


Fig. 4 Root water loss plotted against area/volume ratio after (a) $30 \mathrm{~min}$; (b) $1 \mathrm{~h}$; (c) $2 \mathrm{~h}$; (d) $5 \mathrm{~h}$; (e) 24 h drying. Dashed lines represent best-fitted curves. Best-fit equations and corresponding $\mathrm{R}^{2}$ are given in Table 2

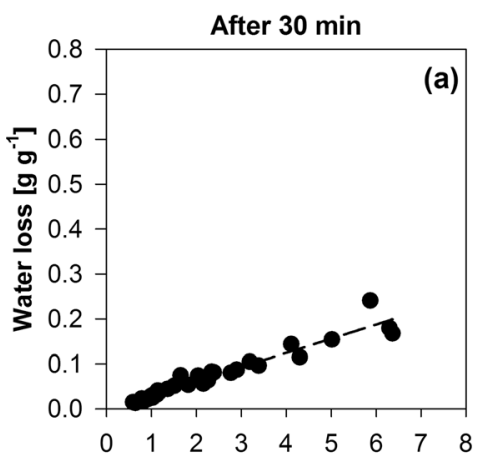

Root area/volume $\left[\mathrm{mm}^{2} \mathrm{~mm}^{-3}\right]$

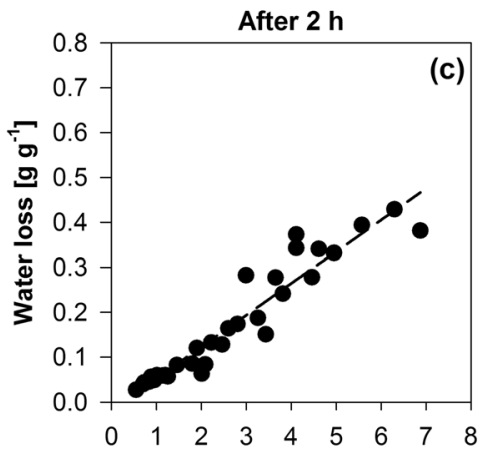

Root area/volume $\left[\mathrm{mm}^{2} \mathrm{~mm}^{-3}\right]$

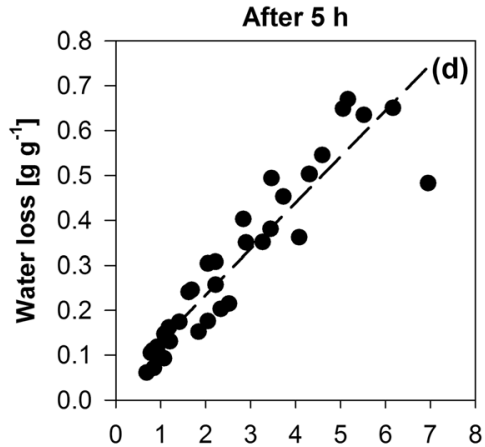

Root area/volume $\left[\mathrm{mm}^{2} \mathrm{~mm}^{-3}\right]$

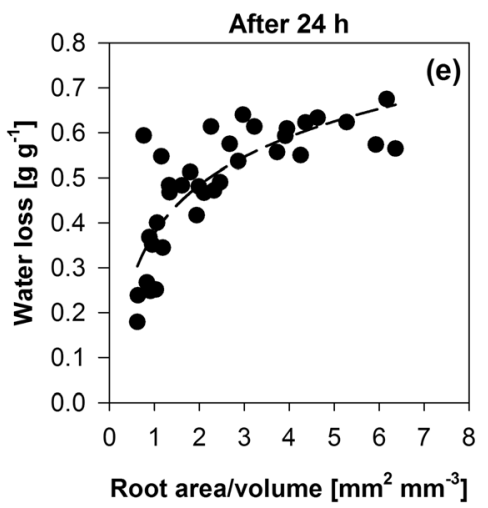

Table 2 Summary of best-fit equations, $\mathrm{R}^{2}$ and number of samples (n) for the relations between root area/volume ratio $(A / V)$ and water loss $\left(W_{L}\right)$ in different treatments (Fig. 4)

\begin{tabular}{llll}
\hline Treatment & Eq & $\mathrm{R}^{2}$ & $\mathrm{n}$ \\
\hline After $30 \mathrm{~min}$ & $W_{L}=0.03 * A / V$ & 0.93 & 31 \\
After $1 \mathrm{~h}$ & $W_{L}=0.04 * A / V$ & 0.82 & 35 \\
After 2 h & $W_{L}=0.07 * A / V-0.02$ & 0.91 & 33 \\
After $5 \mathrm{~h}$ & $W_{L}=0.10 * A / V+0.03$ & 0.87 & 37 \\
After 24 h & $W_{L}=0.38+0.15 * \ln (A / V)$ & 0.64 & 35 \\
\hline
\end{tabular}

increase in dry soil, which had a water content equal to $0.01 \mathrm{~g} \mathrm{~g}^{-1}$ (Table 5). Soil water potential showed extremely negative values in soil with water content of $0.01 \mathrm{~g} \mathrm{~g}^{-1}$ (i.e. $<-70 \mathrm{MPa}$ in dry soil treatment), but did not drop below $-1.0 \mathrm{MPa}$ in the other treatments (Table 5).

Both root tensile strength and Young's modulus showed abrupt increases after 30 days in dry soil (Figs 9e, j; Table 6), where values up to $120 \mathrm{MPa}$ and $5800 \mathrm{MPa}$ were reached, respectively. On the contrary, other treatments did not significantly affect root tensile 

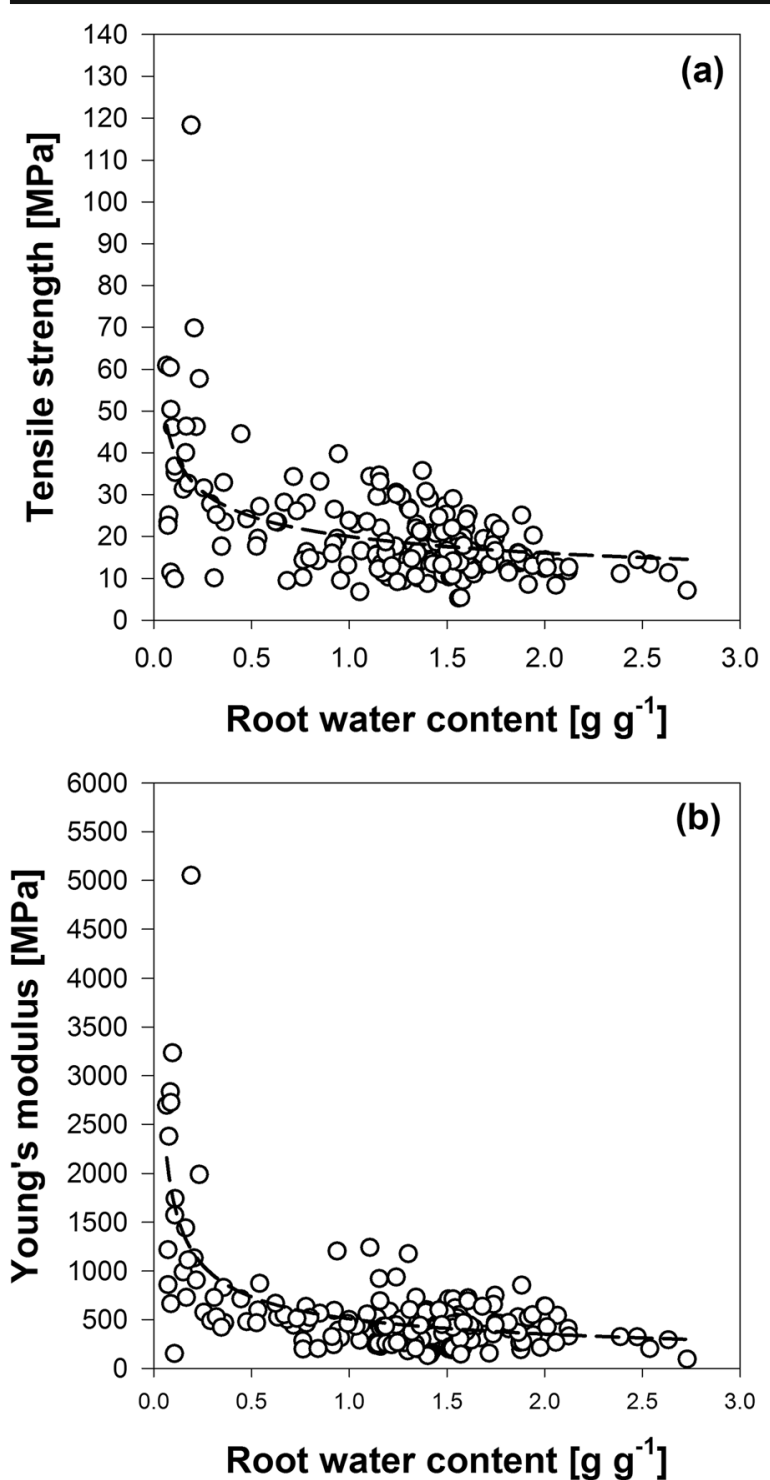

Fig. 5 Root tensile strength (a) and Young's modulus (b) plotted against root water content. Data from all treatments are included. Dashed lines represent the curve fitting. Best-fit equations and the corresponding $\mathrm{R}^{2}$ are given in Table 3

strength and Young's modulus, which did not exceed $40 \mathrm{MPa}$ and $1500 \mathrm{MPa}$ respectively (Fig. 9). Root water

Table 3 Summary of best-fit equations, $\mathrm{R}^{2}$ and number of samples (n) for the relations between biomechanical properties $\left(T_{\mathrm{r}}\right.$ and $\left.E_{r}\right)$ and root water content $\left(W_{C}\right.$; Fig. 5)

\begin{tabular}{llll}
\hline Biomechanical properties & $\mathrm{n}$ & $\mathrm{Eq}$ & $\mathrm{R}^{2}$ \\
\hline Tensile strength & 188 & $T_{r}=19.95^{*} W_{C}^{-0.31}$ & 0.30 \\
Young's modulus & 188 & $E_{r}=507.10^{*} W_{C}^{-0.53}$ & 0.44 \\
\hline
\end{tabular}

content highlighted an abrupt drop after 30 days in dry soil, down to values between 0.07 to $0.13 \mathrm{~g} \mathrm{~g}^{-1}$ (Fig. 10). However, the roots subjected to the other soil treatments showed only a small change in root water content and the average values did not drop below $1.4 \mathrm{~g} \mathrm{~g}^{-1}$ (average value of hydrated roots $=1.76 \pm 0.02 \mathrm{~g} \mathrm{~g}^{-1}$ ).

Only roots in dry soil highlighted a significant diameter decrease by up to $24.4 \pm 0.2 \%$ ( $p$-value of Wilcoxon Matched-Pairs test $<0.001$; data not shown). Changes in root diameter could affect the calculation of tensile strength, which could notably differ if initial (pretreatment) or final (post-treatment; e.g. after 30 days in dry soil) diameter was used in the calculation of tensile strength (Eq. 5; Fig. 11). In fact, the decrease in diameter in dry soil treatment could result in an average $80 \%$ greater tensile strength $(50.7 \pm 3.0 \mathrm{MPa})$ compared with the value calculated from the initial diameter (pre-treatment; $27.9 \pm 1.5 \mathrm{MPa}$ ) when the roots were hydrated. On the contrary, no or minor changes in tensile strength due to diameter could be observed in other treatments $(0.09$, 0.15 and $0.25 \mathrm{~g} \mathrm{~g}^{-1}$ soil $\mathrm{W}_{\mathrm{C}}$; Fig. 11). It must be emphasised that the diameter decrease was not the only factor that caused the increase in tensile strength in dry soil, as result of a calculation effect. Indeed, a $48 \%$ greater average tensile strength $(27.9 \pm 1.5 \mathrm{MPa})$, compared with the average value of hydrated roots $(18.9 \pm 0.5 \mathrm{MPa})$, was measured in dry soil treatment, even when the initial diameter (pre-treatment) was used in the calculations. This greater tensile strength in the dry soil treatment was observed in all diameter classes (Fig. 11) and reflects a greater maximum tensile force at failure.

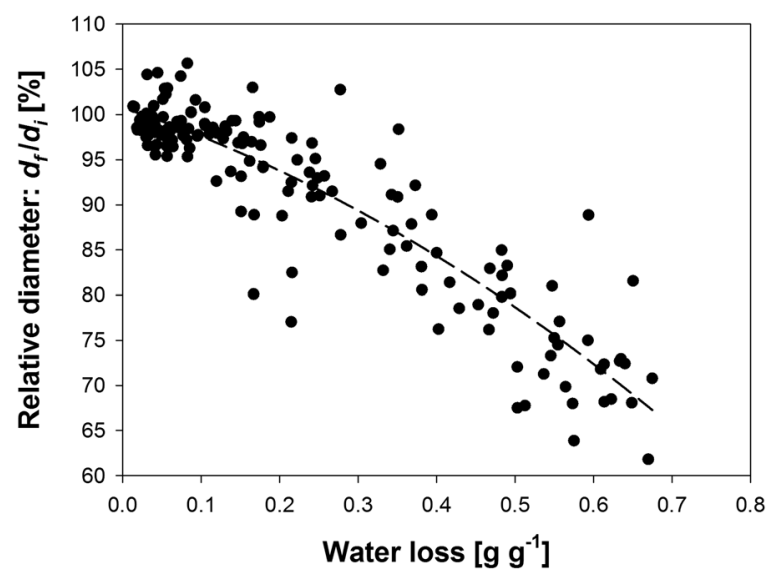

Fig. 6 Relation between root water loss and relative diameter $\left[\% d_{f} / d_{i}=100.78-28.74 * W_{L}-30.00 * W_{L}^{2} ; \mathrm{R}^{2}=0.83 ; n=158\right]$. Note that relative diameter is computed as $\% d_{f} / d_{i}=\left(\frac{\mathrm{d}_{f}}{\mathrm{~d}_{i}}\right) * 10$ 0 (Eq. (7)) 
Fig. 7 Root tensile strength change $\left(\Delta T_{r}\right)$ due to diameter change plotted against initial root diameter, after (a) $30 \mathrm{~min}$; (b) $1 \mathrm{~h}$; (c) $2 \mathrm{~h}$; (d) $5 \mathrm{~h}$; (e) $24 \mathrm{~h}$ drying. Dashed lines represent best-fitted curves. Best-fit equations and the corresponding $\mathrm{R}^{2}$ are given in Table 4
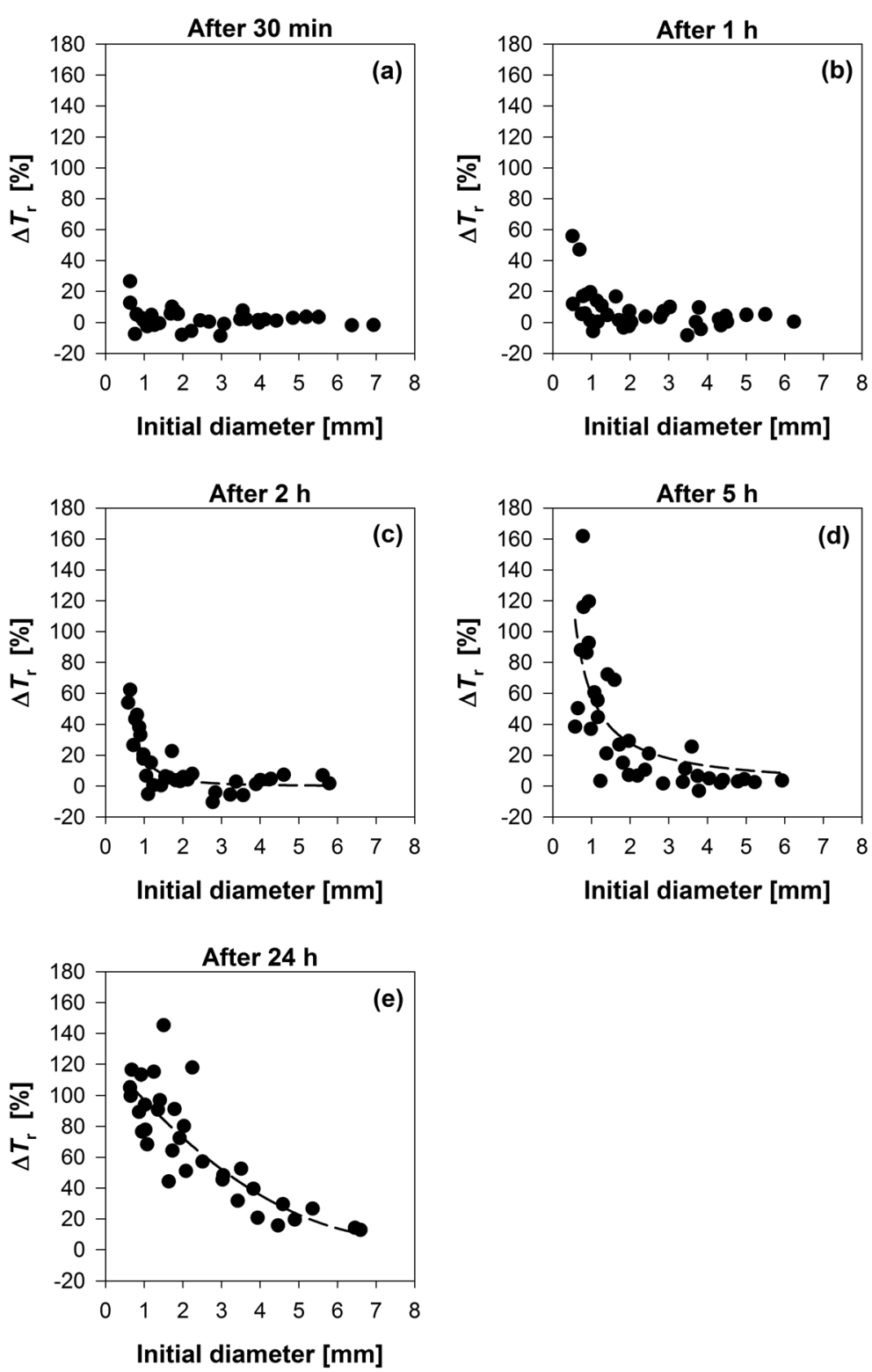

Root water release curve

All root replicates showed a consistent water content versus water potential relation (Fig. 12). The root water release curve highlighted the large capacity of root material to hold water $\left(>2.0 \mathrm{~g} \mathrm{~g}^{-1}\right)$. The decrease in water content from 2.3 to $1.0 \mathrm{~g} \mathrm{~g}^{-1}$ resulted in a decrease (i.e. becoming more negative) in water potential. Subsequently, water potential dropped exponentially as roots lost water further. As roots lost $40 \%$ of their initial water content and had a water content of $1 \mathrm{~g} \mathrm{~g}^{-1}$, the corresponding root water potential lowered (i.e. more
Table 4 Summary of best-fit equations, $\mathrm{R}^{2}$ and number of samples (n) for the relations (Fig. 7) between tensile strength change due to diameter change $\left(\Delta T_{r}\right)$ and root initial diameter $\left(d_{i}\right)$

\begin{tabular}{llll}
\hline Treatment & Eq & $\mathrm{R}^{2}$ & $\mathrm{n}$ \\
\hline After $30 \mathrm{~min}$ & - & - & 33 \\
After $1 \mathrm{~h}$ & - & - & 34 \\
After 2 h & $\Delta T_{r}=18.92 * d_{i}{ }^{-2.27}$ & 0.77 & 33 \\
After $5 \mathrm{~h}$ & $\Delta T_{r}=59.12 * d_{i}{ }^{-1.09}$ & 0.52 & 36 \\
After 24 h & $\Delta T_{r}=125.19-30.21 * d_{i}+1.94 * d_{i}{ }^{2}$ & 0.69 & 33 \\
\hline
\end{tabular}




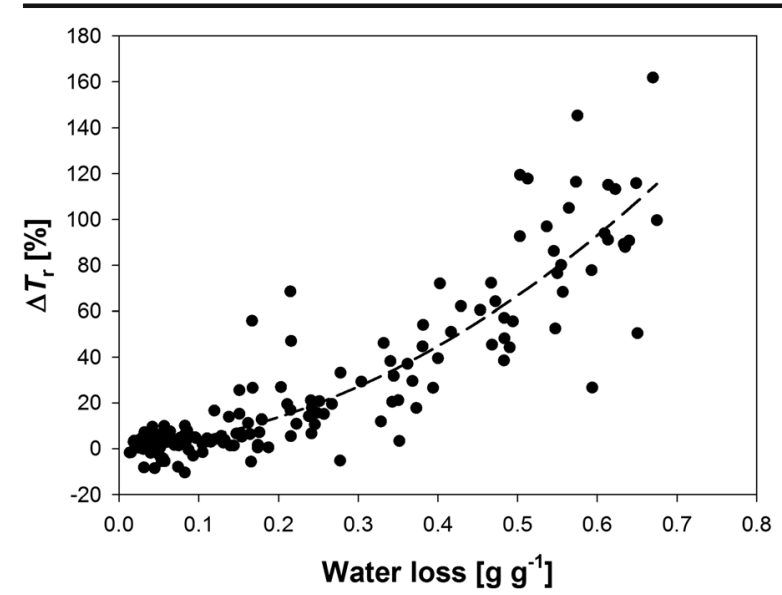

Fig. 8 Relation between root water loss and tensile strength change due to root diameter change. Dashed line represents the best-fitted curve $\left[\Delta T_{r}=-0.08+25.20 * W_{L}+216.36 * W_{L}{ }^{2} ; \mathrm{R}^{2}=\right.$ $0.81 ; \mathrm{n}=158]$

negative) to - 3.0 MPa. It must be highlighted that at -7 to $-8 \mathrm{MPa}$, roots still retained $20 \%\left(0.5 \mathrm{~g} \mathrm{~g}^{-1}\right)$ of their initial water content.

Tensile stress induced by root axial shrinkage

Tensile stress induced upon root drying and shrinkage for all root samples exhibited a consistent behaviour, increasing stress with time in the form of a sigmoidal curve (Fig. 13; Table 7). After the first hour of stress relaxation (i.e. from imposed $1 \mathrm{MPa}$ to $0.4-0.6 \mathrm{MPa}$ ) all roots showed an initial plateau (from 1 to $10 \mathrm{~h}$ ) of stress ranging between 0.4 and $0.6 \mathrm{MPa}$. Subsequently, the induced stress increased almost linearly up to $3.8-$ 6.5 MPa before the root stress approached a peak value.

The water content of tested roots (Table 7) substantially decreased from an initial average value of $1.83 \pm$ 0.08 (i.e. at test start) to a final value of $0.10 \pm 0.00 \mathrm{~g} \mathrm{~g}^{-1}$ (i.e. at the end of the test). Final water content was consistent with values measured after 30 days in dry soil (Fig. 10). After the $72 \mathrm{~h}$ test the tensile strength and Young's modulus of roots showed average values of
$37.0 \pm 4.2 \mathrm{MPa}$ and $3219.9 \pm 274.7 \mathrm{MPa}$, respectively (Table 7).

Root segments tested for $24 \mathrm{~h}$ (Fig. 14) generally showed a small increase in stress, except one root segment that highlighted a remarkable increase in stress. The maximum stress value (3.9 MPa) was measured in the $1.03 \mathrm{~mm}$ diameter root. Moreover, this particular root segment showed also the lowest water content $\left(0.10 \mathrm{~g} \mathrm{~g}^{-1}\right)$ after $24 \mathrm{~h}$ test (Table 8$)$. After $24 \mathrm{~h}$ test, the tensile strength and Young's modulus of roots showed average values of $22.5 \pm 1.0 \mathrm{MPa}$ and $871.3 \pm$ 191.9 MPa, respectively. The greatest tensile strength (27.9 MPa) and Young's modulus (2238.3 MPa) values were measured in a $1.03 \mathrm{~mm}$ diameter root. Note that the root segment with the lowest final water content had the greatest induced stress, tensile strength and Young's modulus (Table 8).

\section{Discussion}

Our study highlighted a remarkable effect of root water status on root biomechanical properties (Figs 1, 2, and 5) as root tensile strength and Young's modulus both showed abrupt increases when root water content dropped below $0.5 \mathrm{~g} \mathrm{~g}^{-1}$ (Fig. 5). The strength increase was mainly because of changes in root diameter associated with evaporation and reduction in root water potential (Figs. 7 and 8). The amount of water loss and strength increase were both dependent on the initial root diameter. Roots with a smaller diameter would have a larger evaporative surface per volume than thicker roots (Figs. 3 and 4).

Biomechanical properties of hydrated roots

Root tensile strength and Young's modulus in hydrated root segments (i.e. no drying treatment or equilibration in soil) averaged $18.0 \pm 0.5$ and $406.9 \pm 15.2 \mathrm{MPa}$ (Figs. 2a, g and 9 a, f), consistently with previous test results on $U$. europaeus growing in a controlled

Table 5 Summary of soil water content and potential per each soil treatment after 30 days burial of roots

\begin{tabular}{llc}
\hline Soil treatment & Soil water content $\left[\mathrm{g} \mathrm{g}^{-1}\right]$ & Soil water potential [-MPa] \\
\hline $0.25 \mathrm{~g} \mathrm{~g}^{-1}$ soil W & $0.00 \pm 0.00$ \\
$0.15 \mathrm{~g} \mathrm{~g}^{-1}$ soil W & $0.23 \pm 0.00$ & $0.03 \pm 0.03$ \\
$0.09 \mathrm{~g} \mathrm{~g}^{-1}$ soil W & $0.15 \pm 0.00$ & $0.87 \pm 0.01$ \\
Dry soil & $0.09 \pm 0.00$ & $73.17 \pm 2.07$ \\
\hline
\end{tabular}


Tensile strength
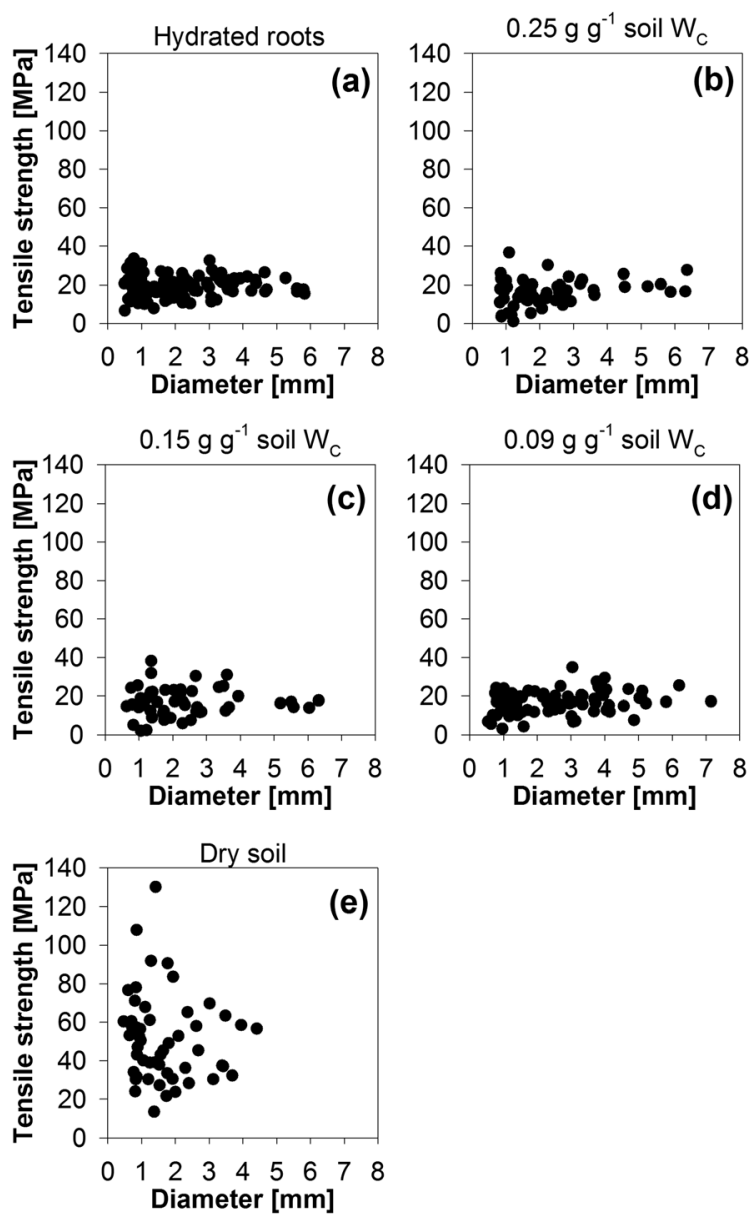

Fig. 9 Root biomechanical properties plotted against final diameter (after treatment). Root tensile strength for (a) hydrated roots not buried in soil; (b) 30 days in soil at $0.25 \mathrm{~g} \mathrm{~g}^{-1} \mathrm{~W}_{\mathrm{C}}$; (c) 30 days in soil at $0.15 \mathrm{~g} \mathrm{~g}^{-1} \mathrm{~W}_{\mathrm{C}}$; (d) 30 days in soil at $0.09 \mathrm{~g} \mathrm{~g}^{-1} \mathrm{~W}_{\mathrm{C}}$; (e)

environment (Boldrin et al. 2017a; Liang et al. 2017). Tensile strength of $U$. europaeus was also close to that reported for similar species belonging to the Fabaceae

Table 6 Summary of the average tensile strength and Young's modulus of each treatment. Number of samples (n) is also given. Letters indicate significant differences among treatments, as tested

\section{Young's modulus}
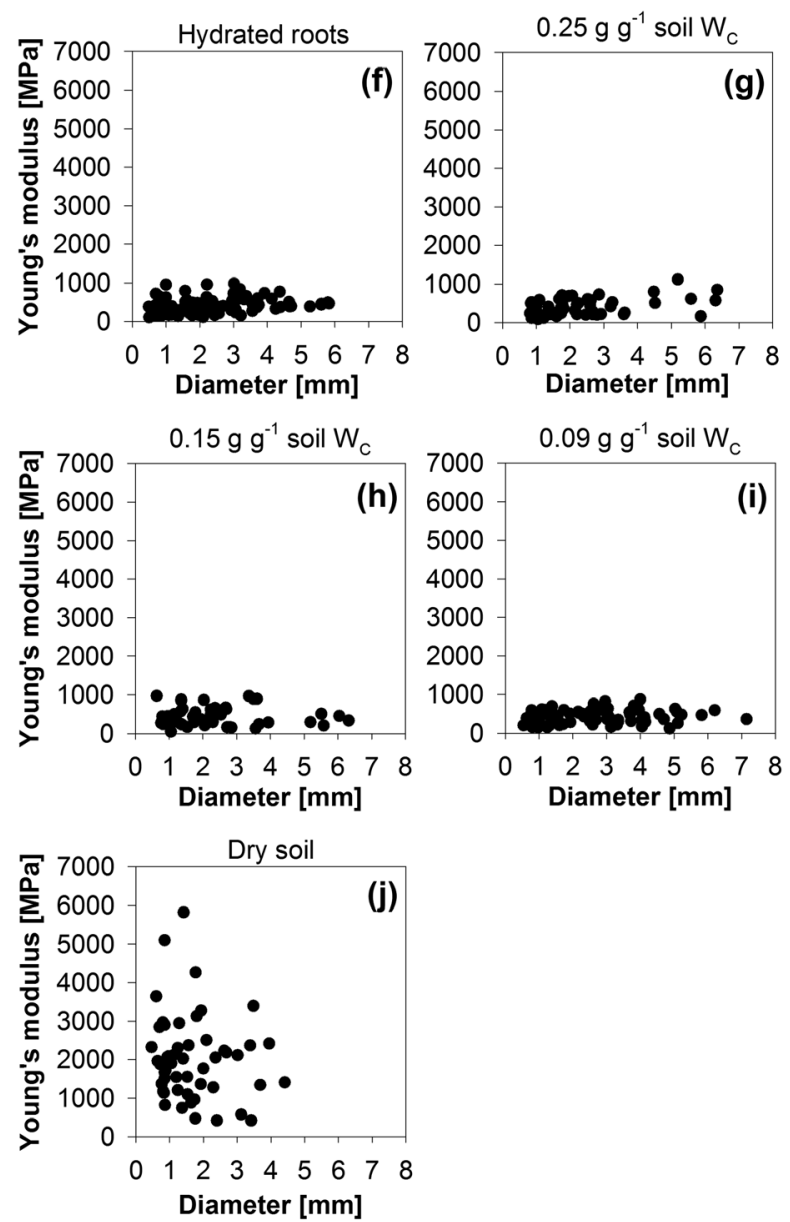

30 days in dry soil. Young's modulus for (f) hydrated roots - not buried in soil; (g) 30 days in soil at $0.25 \mathrm{~g} \mathrm{~g}^{-1} \mathrm{~W}_{\mathrm{C}}$; (h) 30 days in soil at $0.15 \mathrm{~g} \mathrm{~g}^{-1} \mathrm{~W}_{\mathrm{C}}$; (i) 30 days in soil at $0.09 \mathrm{~g} \mathrm{~g}^{-1} \mathrm{~W}_{\mathrm{C}}$; (j) 30 days in dry soil

family such as Spartium Junceoum (i.e. $17 \mathrm{MPa}$; Stokes et al. 2008). However, our hydrated roots of $U$. europaeus can be considered weak if compared with

using one-way ANOVA followed by post hoc Tukey's test. Tensile strength and Young's modulus data were, respectively, square root and log-transformed in statistical analysis

\begin{tabular}{llll}
\hline Treatments & n samples & Average tensile strength [MPa] & Average Young' modulus [MPa] \\
\hline Hydrated roots & 112 & $18.62 \pm 0.53 \mathrm{a}$ & $400.94 \pm 17.94 \mathrm{a}$ \\
$0.25 \mathrm{~g} \mathrm{~g}^{-1}$ soil W & 53 & $15.79 \pm 0.98 \mathrm{a}$ & $400.92 \pm 30.13 \mathrm{a}$ \\
$0.15 \mathrm{~g} \mathrm{~g}^{-1}$ soil W & 49 & $16.68 \pm 1.07 \mathrm{a}$ & $441.53 \pm 34.85 \mathrm{a}$ \\
$0.09 \mathrm{~g} \mathrm{~g}^{-1}$ soil W & 79 & $16.80 \pm 0.66 \mathrm{a}$ & $424.40 \pm 19.37 \mathrm{a}$ \\
Dry soil & 53 & $50.33 \pm 3.01 \mathrm{~b}$ & $2026.49 \pm 149.69 \mathrm{~b}$ \\
\hline
\end{tabular}


the values reported in literature for woody species (e.g. values up to $731 \mathrm{MPa}$ for Fagus sylvatica reported by Bischetti et al. (2005)). Similarly, our hydrated roots showed maximum Young's modulus values of less than $1000 \mathrm{MPa}$, while based on the relatively limited data available in the literature thin woody roots can have Young's modulus greater than $3000 \mathrm{MPa}$ (Fan and $\mathrm{Su}$ 2008; Mickovski et al. 2009).

Root drying and biomechanical properties

Root tensile strength and Young's modulus remained constant with diameter (after treatment) until 5 and $24 \mathrm{~h}$ after drying treatments were applied (Fig. 2). Following drying (5 and $24 \mathrm{~h}$ ), both root strength and modulus were found to exhibit a negative power law relation with diameter (Figs 2e, f and 1). The elastic-plastic nature of root stress-strain curve was notably affected by drying (Fig. 1). Dry roots showed smaller strain and plastic range compared with hydrated roots, which had much larger strain (i.e. elongation) and plastic deformation in agreement with the study reported by Yang et al. (2016). Therefore, dry roots may mobilise large resistance closer to soil peak strength. On the contrary, it is likely that hydrated roots reach their peak strength at much larger displacement than soil (Meijer et al. 2018; Mickovski

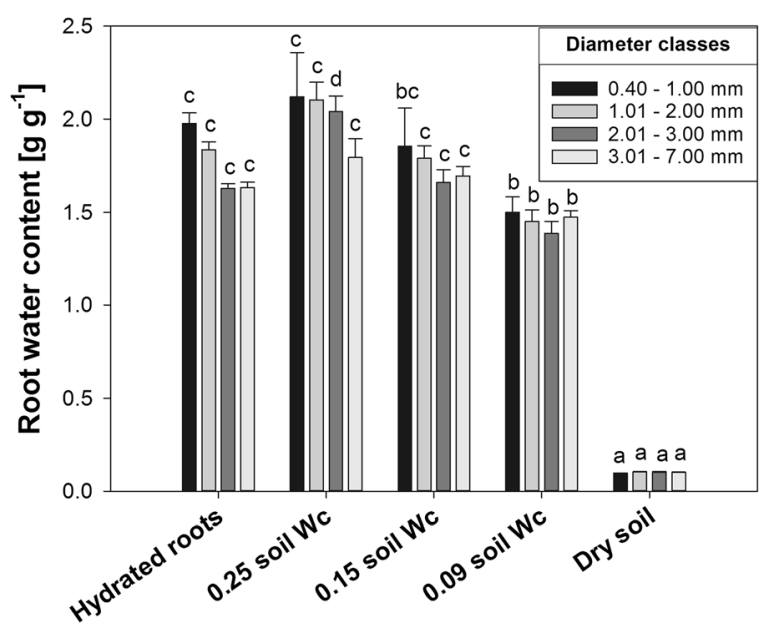

Fig. 10 Root water content per diameter class in different treatments: hydrated roots - not buried in soil; 30 days in soil at $0.25 \mathrm{~g} \mathrm{~g}^{-1} \mathrm{~W}_{\mathrm{C}} ; 30$ days in soil at $0.15 \mathrm{~g} \mathrm{~g}^{-1} \mathrm{~W}_{\mathrm{C}} ; 30$ days in soil at $0.09 \mathrm{~g} \mathrm{~g}^{-1} \mathrm{~W}_{\mathrm{C}}$ and 30 days in dry soil. Means are reported \pm standard error of mean. Letters indicate significant differences among treatments, as tested using one-way ANOVA followed by post hoc Tukey's test. Data were log-transformed in statistical analysis et al. 2009). The observed greater strength and Young's modulus of dry roots, when compared with moist roots, is in agreement with previous studies (Hales et al. 2013; Hales and Miniat 2017; Kurowski et al. 2018; Yang et al. 2016). Hales and Miniat (2017) found that the strength of dry Fagus sylvatica and Picea sitchensis roots were 20 and $50 \%$ greater than that of hydrated roots, respectively. The drastic increase in Young's modulus for thinner roots that dry faster was consistent with the results reported by Kurowski et al. (2018) for non-woody roots in compression. Indeed, Kurowski et al. (2018) found an increase in Young's modulus by a factor of 35 in air-dried roots. In particular, Kurowski et al. (2018) study observed a power law increase in Young's modulus with a decrease in root cross-section area measured at different times of drying. Moreover, the increase in root Young's modulus following drying is also in agreement with studies on lignin and hemicellulose (Cousins 1976, 1978), which are the two main chemical components that contribute to mechanical strength of woody roots (Genet et al. 2005; Hathaway and Penny 1975; Zhang et al. 2014). For instance, the Young's modulus of hemicellulose extracted from Pinus radiata wood varies by almost three orders of magnitude in relation to moisture ranging from nearly saturated to nearly dry conditions (Cousins 1978).

Notable increases in tensile strength and Young's modulus were found also in roots buried in dry soil for 30 days (Figs 9e, j). This is because when the root dried (i.e. equilibrated with surrounding dry soil) and the root water content dropped below about $0.5 \mathrm{~g} \mathrm{~g}^{-1}$, both the tensile strength and Young's modulus showed abrupt increases to values exceeding 100 and $5000 \mathrm{MPa}$, respectively (Fig. 5). On the contrary, the roots subjected to the other soil treatments (i.e. soil water content between $0.25\left(\approx\right.$ field capacity) and $\left.0.09 \mathrm{~g} \mathrm{~g}^{-1}\right)$ had a final water content greater than $1.0 \mathrm{~g} \mathrm{~g}^{-1}$. Root water content of $1.0 \mathrm{~g} \mathrm{~g}^{-1}$ or greater had no, or minimal, effect on biomechanical properties (Fig. 9). This could be mainly explained by the water potential gradient between the root and the surrounding soil. Soil water potential of these treatments (i.e. soil $\mathrm{W}_{\mathrm{C}}=$ between 0.25 and $0.09 \mathrm{~g} \mathrm{~g}^{-1}$ ) was $\geq-1 \mathrm{MPa}$ (Table 5). Therefore, the soil water potential was not negative enough to drive moisture out from the root, as highlighted by the water release curve of U. europaeus roots (Fig. 12). Results highlighted that the sandy loam tested in this study does not reach enough negative water potential to cause 

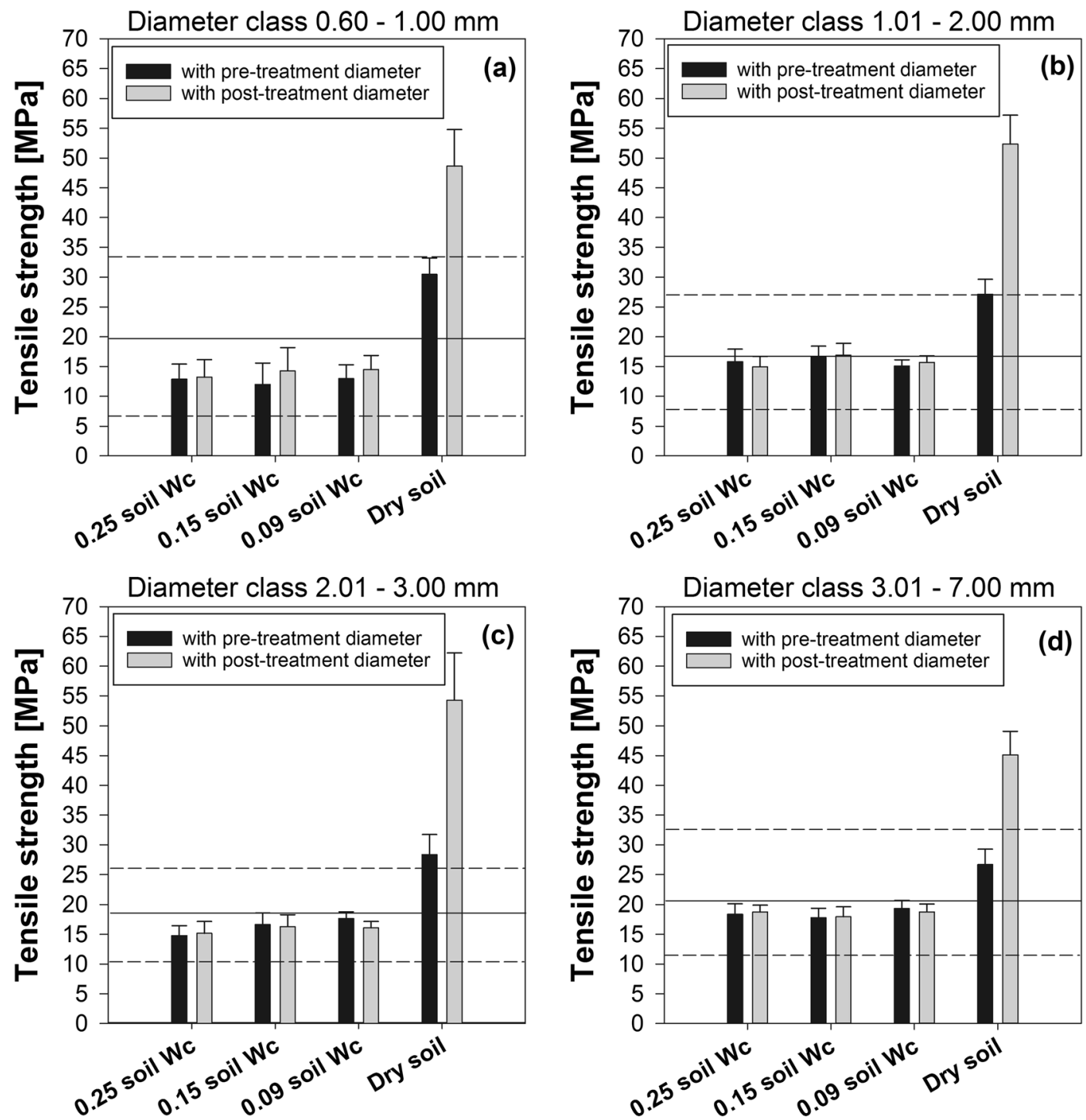

Fig. 11 Root tensile strength calculated using pre- and posttreatment root diameter (i.e. initial and final diameter) for each treatment in pre-treatment diameter (i.e. initial $d$ ) classes (a) 0.60 $1.00 \mathrm{~mm}$; (b) 1.01-2.00 mm; (c) 2.01-3.00; (d) 3.01-7.00 mm.

changes in both root water content and root biomechanical properties except when the soil is dry. However, clay soils would have more negative water potentials for a given water content, when compared with the sandy soil tested in this study. It must be noted that our root sections were not part of a living plant and hence not connected to the low (i.e. more negative) water potential in the atmosphere through the soil-plant-atmosphere continuum as happens in transpiring plants (Nardini et al. 2003; Steudle 2000, 2001; Steudle and Peterson 1998).

Means are reported \pm standard error of mean. Solid line represents the mean value of tensile strength in hydrated roots while dashed lines represent minimum and maximum values of tensile strength in hydrated roots in the same diameter class

Root shrinkage and strength increase

The increase of root tensile strength can be mainly explained by the decrease of diameter as roots dry (Figs 6, 7 and 8). In our study, root drying induced a diameter decrease (e.g. 30\% shrinkage; Fig. 6), which is similarly observed in previous studies for both woody and herbaceous species (Boldrin et al. 2017b; Carminati et al. 2013, 2009; Huck et al. 1970). The small diameter increase (no more than 5\%) observed in a few roots after initial water loss (Fig. 6) may be explained by the bark 


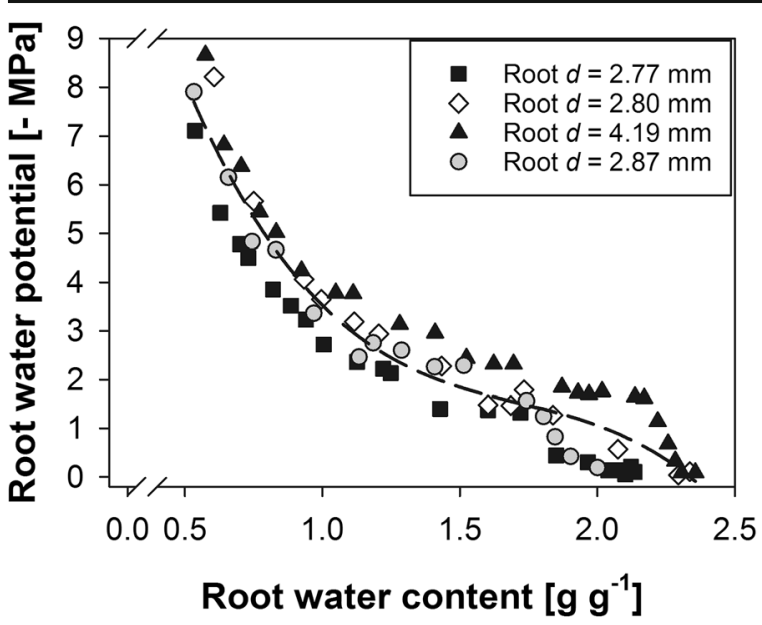

Fig. 12 Relation between root water content and root water potential $\left(\Psi_{r}\right)$ measured in four root segments $\left[\Psi_{r}=17.71-25.46\right.$ $\left.* W_{C}+14.00 * W_{C}{ }^{2}-2.72 * W_{C}{ }^{3} ; \mathrm{R}^{2}=0.92 ; n=74\right]$. The initial root diameters $(d)$ are given in the legend

cracking, previously observed also by Yang et al. (2016). However, this small diameter increase was limited to a few roots during early dehydration (i.e. $30 \mathrm{~min}$ ) and likely to be of negligible importance. Because root strength is calculated by dividing a root breaking force by the corresponding root cross-sectional area (Eq. 5), the increase in strength of dry roots could be a calculation effect of diameter decrease (Figs. 7 and 8). For example, a strength increase by up to $116 \%$ was

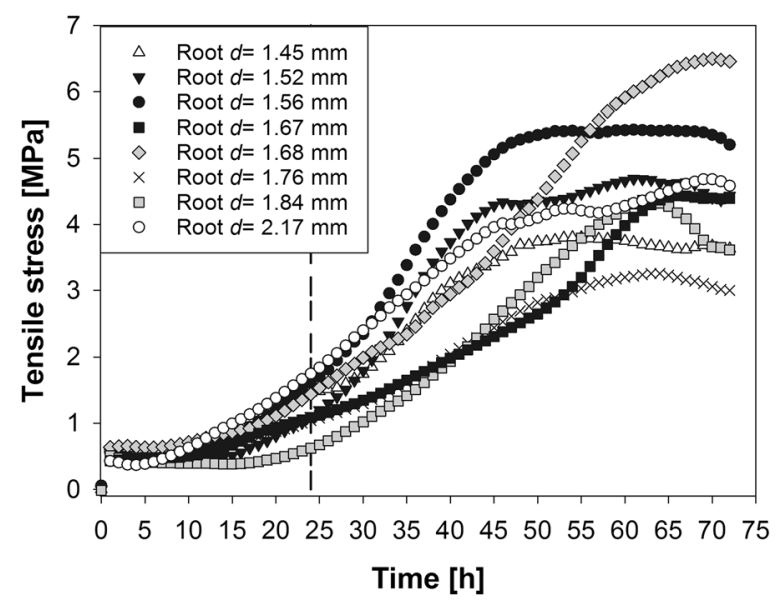

Fig. 13 Tensile stress induced by root axial contraction with time (72 h). Symbols represent stress values at $1 \mathrm{~h}$ intervals for eight root samples. The initial diameters $(d)$ of tested roots are given in the figure legend. Dashed line indicates $24 \mathrm{~h}$ from test start (i.e. $24 \mathrm{~h}$ drying). Time 0 corresponds to the start of the experiment (i.e. start of the root stretching to $1 \mathrm{MPa}$ ). Note that the stretched roots reached $1 \mathrm{MPa}$ in less than $1 \mathrm{~min}$ from the experiment start. Summary of test results are given in Table 7 calculated when final diameter $(32 \%$ diameter shrinkage) was used instead of initial diameter (pre-treatment diameter before root drying). The observed decrease in root diameter and increase in root tensile strength for roots buried in dry soil is in agreement with that reported by Watson et al. (1997) for root strength deterioration after tree death (Kunzea ericoides). Watson et al. (1997) observed an increase in root tensile strength suggesting an effect of root moisture loss and consequent decrease in root diameter during the first 12 months from tree death. Strength of roots decreased only after 12 months from tree death due to root tissue decay. Therefore, the present study may provide insights into the effects of soil moisture on root biomechanical properties after tree felling, as root segments buried in soils with different water contents, can closely resemble tree roots after plant death.

Root diameter dependence of root water loss, shrinkage and strength

In our study, the root water loss, and hence water content, was strongly diameter-dependent due to smaller diameter roots having a faster rate of water loss when compared to larger diameter roots. The diameter dependence of both water loss and water content can be explained by the relation between root evaporative surface and the root water capacitance (i.e. root volume). Indeed, water loss is strongly related to the root area/ volume ratio (Fig. 4). As root diameter increases, root area/volume ratio inversely decreases according to root geometry. For example, a $1 \mathrm{~mm}$ diameter root has an area/volume ratio equal to four, while a $4 \mathrm{~mm}$ diameter root has an area/volume ratio equal to one. The evaporative surface/water capacitance ratio (i.e. area/volume ratio) is commonly recognized as one of the main factors affecting plant water relation in above-ground organs (Mauseth 2000). In particular, Kurowski et al. (2018) showed that nonwoody roots dry more or less rapidly depending on the root aspect ratio, calculated as root volume per airexposed outer surface of the root.

Root shrinkage and strength increase were strongly related to initial root diameter as already observed for root water loss and water content (Figs. 3 and 7; Suppl. Fig. 1). Compared to thick roots, thin roots $(<2 \mathrm{~mm})$ had a faster rate of water loss, greater diameter decrease and hence greater strength increase (Figs 3 and 7). Moreover, the shrinkage of large roots may be limited 
Table 7 Summary of diameter, maximum induced stress, fitted equation for stress $\left(S_{r}\right)$ - time $(t)$ relation with $\mathrm{R}^{2}$, initial and final water content of each tested root sample (Fig. 13). Initial and final water contents were measured right before and after the test (i.e. after $72 \mathrm{~h}$ ), respectively. Tensile strength at maximum load and Young's modulus, measured at the end of the test are also given. Note that tensile strength and Young's modulus were calculated using the initial diameter before testing

\begin{tabular}{lllllllll}
\hline Root & $\begin{array}{l}\text { Diameter } \\
{[\mathrm{mm}]}\end{array}$ & $\begin{array}{l}\text { Max stress } \\
{[\mathrm{MPa}]}\end{array}$ & Fitted equation & $\mathrm{R}^{2}$ & $\begin{array}{l}\text { Initial } \\
\mathrm{W}_{\mathrm{C}}\left[\mathrm{g} \mathrm{g}^{-1}\right]\end{array}$ & $\begin{array}{l}\text { Final } \\
\mathrm{W}_{\mathrm{C}}\left[\mathrm{g} \mathrm{g}^{-1}\right]\end{array}$ & $\begin{array}{l}\text { Tensile } \\
\text { strength }[\mathrm{MPa}]\end{array}$ & $\begin{array}{l}\text { Young's } \\
\mathrm{modulus}[\mathrm{MPa}]\end{array}$ \\
\hline 1 & 1.45 & 3.8 & $S_{r}=3.9 /(1+\exp .(-(t-28.8) / 10.3))$ & 0.98 & 1.98 & 0.09 & 22.9 & 2126.2 \\
2 & 1.53 & 4.7 & $S_{r}=4.7 /(1+\exp .(-(t-31.8) / 7.1))$ & 0.99 & 1.82 & 0.09 & 38.7 & 3669.5 \\
3 & 1.56 & 5.4 & $S_{r}=5.6 /(1+\exp .(-(t-30.9) / 7.9))$ & 0.99 & 1.46 & 0.09 & 32.7 & 3963.8 \\
4 & 1.67 & 4.4 & $S_{r}=6.8 /(1+\exp .(-(t-56.4) / 18.7))$ & 0.99 & 1.67 & 0.12 & 57.5 & 3893.8 \\
5 & 1.68 & 6.5 & $S_{r}=8.2 /(1+\exp .(-(t-47.7) / 15.1))$ & 0.99 & 1.71 & 0.11 & 41.3 & 3866.8 \\
6 & 1.76 & 3.3 & $S_{r}=3.5 /(1+\exp .(-(t-35.1) / 13.0))$ & 0.98 & 2.22 & 0.10 & 21.1 & 2054.3 \\
7 & 1.84 & 4.4 & $S_{r}=4.4 /(1+\exp .(-(t-41.1) / 9.4))$ & 0.98 & 1.79 & 0.10 & 44.4 & 3160.5 \\
8 & 2.17 & 4.7 & $S_{r}=4.6 /(1+\exp .(-(t-28.9) / 10.2))$ & 0.99 & 2.01 & 0.09 & 37.0 & 3024.6 \\
\hline
\end{tabular}

by a relatively greater volume occupied by heartwood compared with thinner and younger roots where cortex and sapwood are relatively more abundant. Previous observations on stems found a notable change in diameter due to sapwood shrinkage but no change in diameter imputable to heartwood (Irvine and Grace 1997). Therefore, it is reasonable to hypothesise that the diameter dependence of root water loss and hence strength increase is one of the factors that causes high strength variability in small diameter roots and negative diameter versus strength power relation frequently reported in the literature (Ghestem et al. 2014a; Mattia et al. 2005; Mickovski et al. 2009), in addition to factors such as root chemical composition and anatomical development (Boldrin et al. 2017b; Genet et al. 2005; Mao et al. 2018; Zhang et al. 2014).

Root axial contraction and strength increase as roots dry

Our test results showed that the diameter decrease due to root drying was not the only factor that causes the increase of tensile strength due to the calculation effect. Indeed, the average root tensile strength $(27.9 \pm$ $1.5 \mathrm{MPa}$ ) in dry soil treatment was higher than that of hydrated roots $(18.9 \pm 0.5 \mathrm{MPa})$ even when initial diameter (i.e. pre-treatment) was used in the calculations (Fig. 11). This empirical strength increase (i.e. not resulting from the calculation effect) could be explained by the "axial contraction (i.e. material compression)" of roots during drying. Root drying and the consequent tissue contraction could induce a tensile stress up to
6.5 MPa after $72 \mathrm{~h}$ (Fig. 13; Table 7). Roots buried in dry soil for 30 days (Figs. 9 and 11) might be subjected to analogous tissue contraction as these roots had the same final root water content $\left(0.10 \mathrm{~g} \mathrm{~g}^{-1}\right)$ of roots tested for $72 \mathrm{~h}$ in contraction versus time experiment. The low water potential (e.g. $<-3 \mathrm{MPa}$ ) developed in drying roots (e.g. $\mathrm{W}_{\mathrm{C}}<1.0 \mathrm{~g} \mathrm{~g}^{-1}$; Fig. 12) induced root tissue contraction probably because of high water surface tension and adhesive force between water molecules and root tissues (e.g. xylem walls). The hypothesis of tensile strength increase due to axial contraction of dry roots is

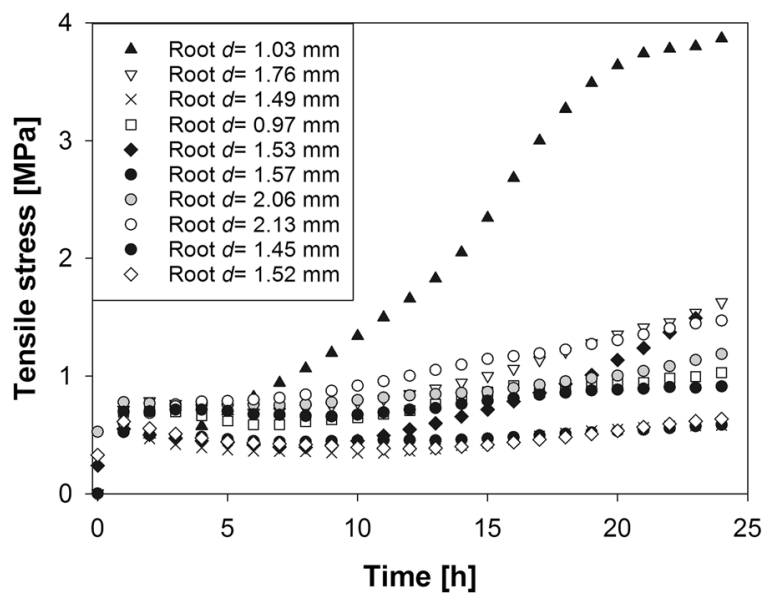

Fig. 14 Tensile stress induced by root axial contraction with time (24 h). Symbols represent stress values at $1 \mathrm{~h}$ intervals for ten root samples. Time 0 corresponds to the start of the experiment (i.e. start of the root stretching to $1 \mathrm{MPa}$ ). Note that the stretched roots reached $1 \mathrm{MPa}$ in less than $1 \mathrm{~min}$ from the experiment start. The initial diameters $(d)$ of tested roots are given in the figure legend. Summary of test results are given in Table 8 
Table 8 Summary of diameter, maximum induced stress, initial and final water content for each tested root sample (Fig. 14). Initial and final water contents were measured right before and after the test (i.e. after $24 \mathrm{~h}$ ), respectively. Tensile strength at maximum load and Young's modulus, measured at the end of the test are also given. Note that tensile strength and Young's modulus were calculated using the initial diameter before testing

\begin{tabular}{lllllll}
\hline Root & Diameter $[\mathrm{mm}]$ & Max stress $[\mathrm{MPa}]$ & Initial $\mathrm{W}_{\mathrm{C}}\left[\mathrm{g} \mathrm{g}^{-1}\right]$ & Final $\mathrm{W}_{\mathrm{C}}\left[\mathrm{g} \mathrm{g}^{-1}\right]$ & Tensile strength [MPa] & Young's modulus [MPa $]$ \\
\hline 1 & 0.97 & 1.0 & 2.12 & 0.36 & 23.8 & 563.9 \\
2 & 1.03 & 3.9 & 2.29 & 0.10 & 27.9 & 2238.3 \\
3 & 1.45 & 0.9 & 2.20 & 0.48 & 19.5 & 587.7 \\
4 & 1.49 & 0.6 & 1.79 & 0.29 & 18.9 & 544.2 \\
5 & 1.52 & 0.6 & 1.84 & 0.32 & 22.8 & 563.6 \\
6 & 1.53 & 1.5 & 1.46 & 0.18 & - & 527.2 \\
7 & 1.57 & 0.6 & 2.11 & 0.55 & 25.8 & 745.6 \\
8 & 1.76 & 1.6 & 1.60 & 0.32 & 17.9 & 705.88 \\
9 & 2.06 & 1.2 & 1.50 & 0.27 & 23.1 & 1365.7 \\
10 & 2.13 & 1.5 & 1.36 & 0.46 & 22.8 & \\
\hline
\end{tabular}

supported by the tensile strength of contracted roots (i.e. after 24 and $72 \mathrm{~h}$ drying), when calculated using the initial diameter (i.e. no calculation effect due to diameter shrinkage). The average tensile strength of contracted roots (i.e. $22.5 \pm 1.0 \mathrm{MPa}$ after $24 \mathrm{~h}$ and $37.0 \pm 4.2 \mathrm{MPa}$ after $72 \mathrm{~h}$ ) was greater than that of hydrated roots (18.0 $\pm 0.5 \mathrm{MPa}$ ). Similarly, the average Young's modulus of contracted roots increased by 2 -fold after $24 \mathrm{~h}(871.3 \pm$ 191.9 MPa) and by 8-fold after $72 \mathrm{~h}(3219.9 \pm$ $274.7 \mathrm{MPa}$ ) compared with hydrated roots $(406.9 \pm$ 15.2 $\mathrm{MPa}$ ). Note that after $24 \mathrm{~h}$ drying, the greatest contractive stress (3.9 MPa; Fig. 14), tensile strength at maximum load (27.9 MPa) and Young's modulus (2238.3 MPa) were measured in the root segment that had the lowest water content $\left(0.10 \mathrm{~g} \mathrm{~g}^{-1}\right.$; Table 8$)$. The greater root tensile strength and Young's modulus highlighted that root contraction may mainly occur in tissues that are relevant to biomechanical properties such as fibres and vessels walls in the xylem (i.e. wood). Hales and Miniat (2017) suggested that strength gain in dry roots may be related to the water decrease in cell walls. Indeed, the water accumulated in the cell wall may affect the bonding of organic polymers. Furthermore, it can be hypothesized that during root contraction, structural changes occur in the orientation of the cellulose microfibrils in cell walls and structure of secondary wall thickening in xylem vessels. For instance, cellulose microfibril orientation in cell walls can affect the biomechanical properties of plant material (Burgert 2006; Hathaway and Penny 1975). Moreover, cell wall thickness and thickening patterns may have a major role on the mechanical properties of the xylem (Karam 2005). Contracted root tissues might therefore have enhanced tensile strength and Young's modulus since more stress is needed to align and stretch the contracted fibrils and fibres in the xylem. Future studies of root anatomical changes upon shrinkage by microscope imaging may offer insights into how microscopic change would drive macroscopic root contraction and biomechanical changes upon root drying. Therefore, the decrease in root water potential (i.e. becoming more negative) can lead to both root diameter decrease and axial contraction of root material, resulting in tensile strength and Young's modulus increase due to both the calculation and empirical effects. Note that the differences among root samples in the same diameter class, in terms of drying rate, contraction stress and biomechanical properties, may be explained by the inherent variability of biological materials such as tissue composition and development.

The idea that plant water status (e.g. water potential) causes shrinkage in plant roots and stems is widely supported by previous studies (Carminati et al. 2013; Génard et al. 2001; Huck et al. 1970; Irvine and Grace 1997; Lövdahl and Odin 1992; Simonneau et al. 1993; Ueda and Shibata 2001). Irvine and Grace (1997) suggested to use stem diameter change and wood elastic properties to estimate water tension (i.e. water potential) in tree xylem. Previous studies noted that diameter shrinkage due to water potential shows a marked hysteresis (Garnier and Berger 1986; Génard et al. 2001). The hysteresis of diameter, and hence tensile strength, change should be investigated in relation to root pre-test 
processing such as drying and re-wetting of samples (Bischetti et al. 2005; Hales et al. 2013).

Roots in a living plant are part of the soil-plantatmosphere continuum, where the water potential in the root xylem should follow closely that of the aboveground organs of the plant (e.g. leaves) that are in contact with the atmosphere. Therefore, our drying roots may approximate the conditions experienced by the roots of an actively transpiring plant during drought periods (e.g. water stressed anisohydric plants). For example, Huck et al. (1970) found that root diameter can shrink up to $40 \%$ (compared with maximum diameter) under dry, sunny days. In particular, root tissues shrink by $25 \%$ when leaf water potential falls to about $-1.5 \mathrm{MPa}$ (Faiz and Weatherley 1982). Recent studies confirmed root shrinkage in transpiring plants through x-ray tomography (Carminati et al. 2013, 2009). Carminati et al. (2013) showed that root shrinkage during water deficit occurs as a direct consequence of plant water stress (i.e. plant water potential decrease) and then continues to increase in a chain reaction because the reduced hydraulic conductivity at root-soil gaps further enhances plant water stress. Therefore, we can hypothesise that high transpiration is beneficial to slope stability by both hydrologic reinforcement (Boldrin et al. 2017a; Kim et al. 2017; Leung et al. 2014; Leung et al. 2017; PollenBankhead and Simon 2010) and root strength and stiffness enhancement. Further studies are necessary to understand the effects of root diameter shrinkage on the soil-root interface friction as well as the effects of roots contraction on the surrounding soil (e.g. soil compression; subsurface flow).

\section{Implications to experimental protocols}

Our results highlight that great attention should be paid to carefully control (e.g. store in moist environment) or measure root moisture during root sampling, storage and testing, in order to avoid overestimation of root tensile strength due to root drying (e.g. diameter shrinkage). We argue that future testing protocols for root biomechanical properties need to account for the effects of root moisture. Moreover, our test results support the statement made by Hales et al. (2013) that laboratory testing of roots must be performed on fully hydrated roots, which likely represents the root moisture condition during rainfall-induced landslide and a more conservative (i.e. weaker roots) condition for root cohesion estimation and slope stability calculation.

\section{Conclusions}

Our study highlights a large effect of root water status on root biomechanical properties. Both root tensile strength and Young's modulus showed an abrupt increase when root water content dropped below $0.5 \mathrm{~g} \mathrm{~g}^{-1}$. In particular, the amounts of root water loss and strength increase were diameter-dependent (e.g. following a negative power relation) because of the relatively larger evaporative surface per volume of small diameter roots. Therefore, root water status may be one of the factors that causes high strength variability in small diameter roots and the negative diameter versus strength power law relation frequently reported in the literature. Abrupt increases in strength and Young's modulus were also measured in roots buried in dry soil for 30 days. On the contrary, in wetter soils roots did not show any notable effect on diameter and biomechanical properties because the corresponding water potentials of the tested sandy soil were not negative enough to drive moisture out from the root, as highlighted by the root water release curve. The observed strength increase in drier roots can be explained by both root diameter reduction (i.e. shrinkage) upon dehydration and root material axial contraction (i.e. compression) due to water potential drop following drying. We suggest that the root moisture must be accounted in biomechanical testing, where careful control of constant and consistent root water content is desirable across all the root diameter classes being tested. For conservative use in soil bioengineering applications we suggest that protocols of biomechanical testing should be improved to use fully hydrated roots or record water content of material before testing.

This study was performed on root sections excavated from soil for one woody species. Further work is needed to improve the understanding of root drying on biomechanical properties in different species with contrasting root anatomy (e.g. woody vs herbaceous). Moreover, the effect of transpiration and soil drying on root shrinkage and hence root strength in living plants should be investigated.

Acknowledgements The authors acknowledge funding from the EPSRC (EP/N03287X/1) and EU FP7 Marie Curie Career Integration Grant (CIG) under the project "BioEPIC slope". The authors thank Kenneth Loades (The James Hutton Institute), Jim McNicol (Biomathematics and Statistic Scotland) and the reviewers Evelyne Kolb and Zhun Mao for helpful comments and advice. Giles Laverack (Scotia Seeds) provided the root material for this study. The James Hutton Institute receives funding from the Scottish Government. 
Open Access This article is distributed under the terms of the Creative Commons Attribution 4.0 International License (http:// creativecommons.org/licenses/by/4.0/), which permits unrestricted use, distribution, and reproduction in any medium, provided you give appropriate credit to the original author(s) and the source, provide a link to the Creative Commons license, and indicate if changes were made.

\section{References}

Bischetti GB, Chiaradia EA, Simonato T, Speziali B, Vitali B, Vullo P, Zocco A (2005) Root strength and root area ratio of forest species in lombardy (northern Italy). Plant Soil 278: 11-22. https://doi.org/10.1007/s11104-005-0605-4

Bischetti GB, Chiaradia EA, Epis T, Morlotti E (2009) Root cohesion of forest species in the Italian alps. Plant Soil 324: 71-89. https://doi.org/10.1007/s11104-009-9941-0

Boldrin D, Leung AK, Bengough AG (2017a) Correlating hydrologic reinforcement of vegetated soil with plant traits during establishment of woody perennials. Plant Soil:1-15. https://doi.org/10.1007/s11104-017-3211-3

Boldrin D, Leung AK, Bengough AG (2017b) Root biomechanical properties during establishment of woody perennials. Ecol Eng https://doi.org/10.1016/j.ecoleng.2017.05.002, 109, 196, 206

Boldrin D, Leung AK, Bengough AG (2018) Hydrologic reinforcement induced by contrasting woody species during summer and winter. Plant Soil 427:369-390. https://doi. org/10.1007/s11104-018-3640-7

Burgert I (2006) Exploring the micromechanical design of plant cell walls. Am J Bot 93:1391-1401. https://doi.org/10.3732 /ajb.93.10.1391

Carminati A, Vetterlein D, Weller U, Vogel H, Oswald SE (2009) When roots lose contact. Vadose Zone J 8:898-809. https://doi.org/10.2136/vzj2008.0147

Carminati A, Vetterlein D, Koebernick N, Blaser S, Weller U, Vogel HJ (2013) Do roots mind the gap? Plant Soil 367: 651-661. https://doi.org/10.1007/s11104-012-1496-9

Cousins WJ (1976) Elastic modulus of lignin as related to moisture content. Wood Sci Technol 10:9-17. https://doi.org/10.1007 /BF00376380

Cousins WJ (1978) Young's modulus of hemicellulose as related to moisture content. Wood Sci Technol 12:161-167. https://doi.org/10.1007/BF00372862

De Baets S, Poesen J, Reubens B, Wemans K, De Baerdemaeker J, Muys B (2008) Root tensile strength and root distribution of typical Mediterranean plant species and their contribution to soil shear strength. Plant Soil 305:207-226. https://doi. org/10.1007/s11104-008-9553-0

De Baets S, Poesen J, Reubens B, Muys B, De Baerdemaeker J, Meersmans J (2009) Methodological framework to select plant species for controlling rill and gully erosion: application to a Mediterranean ecosystem. Earth Surf Process Landf 34: 1374-1392. https://doi.org/10.1002/esp.1826

De La Barrera E, Smith WK (2009) Perspectives in biophysical plant ecophysiology: a tribute to park S. Nobel. Universidad Nacional Autónoma de México. 400 pp
Faiz SMA, Weatherley PE (1982) Root contraction in transpiring plants. New Phytol 92:333-343

Fan CC, Su CF (2008) Role of roots in the shear strength of rootreinforced soils with high moisture content. Ecol Eng 33: 157-166. https://doi.org/10.1016/j.ecoleng.2008.02.013

Garnier E, Berger A (1986) Effect of water stress on stem diameter changes of peach trees growing in the field. J Appl Ecol 23: 193-209

Génard M, Fishman S, Vercambre G, Huguet JG, Bussi C, Besset J, Habib R (2001) A biophysical analysis of stem and root diameter variations in woody plants. Plant Physiol 126:188202. https://doi.org/10.1104/pp.126.1.188

Genet M, Stokes A, Salin F, Mickovski SB, Fourcaud T, Dumail JF, Van Beek R (2005) The influence of cellulose content on tensile strength in tree roots. Plant Soil 278:1-9. https://doi. org/10.1007/s11104-005-8768-6

Ghestem M, Cao K, Ma W, Rowe N, Leclerc R, Gadenne C, Stokes A (2014a) A framework for identifying plant species to be used as 'Ecological Engineers' for fixing soil on unstable slopes. PLoS One 9. https://doi.org/10.1371/journal. pone. 0095876

Ghestem M, Veylon G, Bernard A, Vanel Q, Stokes A (2014b) Influence of plant root system morphology and architectural traits on soil shear resistance. Plant Soil 377:43-61. https://doi.org/10.1007/s11104-012-1572-1

Giadrossich F, Schwarz M, Cohen D, Cislaghi A, Vergani C, Hubble T, Phillips C, Stokes A (2017) Methods to measure the mechanical behaviour of tree roots: a review. Ecol Eng 109:256-271 https://doi.org/10.1016/j.ecoleng.2017.08.032

Hales TC, Miniat CF (2017) Soil moisture causes dynamic adjustments to root reinforcement that reduce slope stability. Earth Surf Process Landf 42:803-813. https://doi.org/10.1002 /esp.4039

Hales TC, Cole-Hawthorne C, Lovell L, Evans SL (2013) Assessing the accuracy of simple field based root strength measurements. Plant Soil 372:553-565. https://doi. org/10.1007/s11104-013-1765-2

Hathaway RL, Penny D (1975) Root strength in some populus and Salix clones. New Zeal J Bot 13:333-344. https://doi. org/10.1080/0028825X.1975.10430330

Huck MG, Klepper B, Taylor HM (1970) Diurnal variations in root diameter. Plant Physiol 45:529-530

Irvine J, Grace J (1997) Continuous measurements of water tensions in the xylem of trees based on the elastic properties of wood. Planta 202:455-461. https://doi.org/10.1007 /s004250050149

Jotisankasa A, Taworn D (2016) Direct shear testing of clayey sand reinforced with live stake geotechnical. Testing Journal 39. https://doi.org/10.1520/gtj20150217

Karam GN (2005) Biomechanical model of the xylem vessels in vascular plants. Ann Bot 95:1179-1186. https://doi. org/10.1093/aob/mci130

Kim JH, Fourcaud T, Jourdan C, Maeght JL, Mao Z, Metayer J, Meylan L, Pierret A, Rapidel B, Roupsard O, de Rouw A, Sanchez MV, Wang Y, Stokes A (2017) Vegetation as a driver of temporal variations in slope stability: the impact of hydrological processes. Geophys Res Lett 44:4897-4907. https://doi.org/10.1002/2017GL073174

Kurowski P, Vautrin C, Genet P, Hattali P, Peralta y Fabi R, Kolb E (2018) Mechanical properties of drying plant roots: Evolution of the longitudinal Young's modulus of chick-pea 
roots with dessication. https://doi.org/10.13140 /RG.2.230782.59200

Leung AK, Woon KX, Ng CWW (2014) Effects of grass on induced soil suction during evapotranspiration and ponding. Unsaturated soils: research and applications - proceedings of the 6th international conference on unsaturated soils, v. 2, 2014, p. 1373-1379

Leung AK, Kamchoom V, Ng CWW (2017) Influences of rootinduced soil suction and root geometry on slope stability: a centrifuge study. Can Geotech J 54:291-303. https://doi. org/10.1139/cgj-2015-0263

Liang T, Bengough AG, Knappett JA, MuirWood D, Loades KW, Hallett PD, Boldrin D, Leung AK, Meijer GJ (2017) Scaling of the reinforcement of soil slopes by living plants in a geotechnical centrifuge. Ecol Eng 109:207-227. https://doi. org/10.1016/j.ecoleng.2017.06.067

Loades KW, Bengough AG, Bransby MF, Hallett PD (2010) Planting density influence on fibrous root reinforcement of soils. Ecol Eng 36:276-284. https://doi.org/10.1016/j. ecoleng.2009.02.005

Loades KW, Bengough AG, Bransby MF, Hallett PD (2013) Biomechanics of nodal, seminal and lateral roots of barley: effects of diameter, waterlogging and mechanical impedance. Plant Soil 370:407-418. https://doi.org/10.1007/s11104-013$1643-y$

Loades KW, Bengough AG, Bransby MF, Hallett PD (2015) Effect of root age on the biomechanics of seminal and nodal roots of barley (Hordeum vulgare L.) in contrasting soil environments. Plant Soil 395:253-261. https://doi. org/10.1007/s11104-015-2560-z

Lövdahl L, Odin H (1992) Diurnal changes in the stem diameter of Norway spruce in relation to relative humidity and air temperature. Trees 6:245-251. https://doi.org/10.1007 /BF00224344

Mao Z, Saint-André L, Genet M, Mine FX, Jourdan C, Rey H, Courbaud B, Stokes A (2012) Engineering ecological protection against landslides in diverse mountain forests: choosing cohesion models. Ecol Eng 45:55-69. https://doi. org/10.1016/j.ecoleng.2011.03.026

Mao Z, Wang Y, McCormack ML, Rowe N, Deng X, Yang X, Xia S, Nespoulous J, Sidle RC, Guo D, Stokes A (2018) Mechanical traits of fine roots as a function of topology and anatomy. Annals of botany: mcy076-mcy076. https://doi. org/10.1093/aob/mcy076

Mattia C, Bischetti GB, Gentile F (2005) Biotechnical characteristics of root systems of typical Mediterranean species. Plant Soil 278:23-32. https://doi.org/10.1007/s11104-005-7930-5

Mauseth JD (2000) Theoretical aspects of surface-to-volume ratios and water-storage capacities of succulent shoots. Am J Bot 87:1107-1115

Meijer GJ, Bengough G, Knappett J, Loades KW, Nicoll B (2018) In situ measurement of root-reinforcement using the corkscrew extraction method. Can Geotech J https://doi. org/10.1139/cgj-2017-0344

Mickovski SB, Hallett PD, Bransby MF, Davies MCR, Sonnenberg R, Bengough AG (2009) Mechanical reinforcement of soil by willow roots: impacts of root properties and root failure mechanism. Soil Sci Soc Am J 73:1276-1285. https://doi.org/10.2136/sssaj2008.0172
Nardini A, Salleo S, Trifilò P, Lo Gullo MA (2003) Water relations and hydraulic characteristics of three woody species cooccurring in the same habitat. Ann For Sci 60:297-305

Ng CWW, Garg A, Leung AK, Hau BCH (2016) Relationships between leaf and root area indices and soil suction induced during drying-wetting cycles. Ecol Eng 91:113-118. https://doi.org/10.1016/j.ecoleng.2016.02.005

Norris JE, Di Iorio A, Stokes A, Nicoll BC, Achim A (2008) Species selection for soil reinforcement and protection. In: Norris JE, Stokes A, Mickovski SB, Cammeraat E, van Beek R, Nicoll BC, Achim A (Eds.) Slope stability and erosion control: ecotechnological solutions. Springer, Dordrecht, The Netherlands. pp 167-210. https://doi.org/10.1007/9781-4020-6676-4

Pollen-Bankhead N, Simon A (2010) Hydrologic and hydraulic effects of riparian root networks on streambank stability: is mechanical root-reinforcement the whole story? Geomorphology 116:353-362. https://doi.org/10.1016/j. geomorph.2009.11.013

Preti F, Giadrossich F (2009) Root reinforcement and slope bioengineering stabilization by Spanish broom (Spartium junceum L.). Hydrol Earth Syst Sc 13:1713-1726

Saifuddin M, Osman N (2014) Evaluation of hydro-mechanical properties and root architecture of plants for soil reinforcement. Curr Sci 107:845-852

Schwarz M, Lehmann P, Or D (2010) Quantifying lateral root reinforcement in steep slopes - from a bundle of roots to tree stands. Earth Surf Process Landf 35:354-367. https://doi. org/10.1002/esp.1927

Simonneau T, Habib R, Goutouly JP, Huguet JG (1993) Diurnal changes in stem diameter depend upon variations in water content: direct evidence in peach trees. J Exp Bot 44:615621. https://doi.org/10.1093/jxb/44.3.615

Steudle E (2000) Water uptake by roots: effects of water deficit. J Exp Bot 51:1531-1542

Steudle E (2001) The cohesion-tension mechanism and the acquisition of water by plant roots. Annu Rev Plant Physiol 52:847-875. https://doi.org/10.1146/annurev. arplant.52.1.847

Steudle E, Peterson CA (1998) How does water get through roots? J Exp Bot 49:775-788

Stokes A, Norris JE, Van Beek LPH, Bogaard T, Cammeraat E, Mickovski SB, Jenner A, Di Iorio A, Fourcaud T (2008) How vegetation reinforces soil on slopes. Ecotechnological Solutions, Slope Stability and Erosion Control, pp 65-118. https://doi.org/10.1007 1978-1-4020-6676-4-4

Stokes A, Atger C, Bengough AG, Fourcaud T, Sidle RC (2009) Desirable plant root traits for protecting natural and engineered slopes against landslides. Plant Soil 324:1-30. https://doi.org/10.1007/s11104-009-0159-y

Tosi M (2007) Root tensile strength relationships and their slope stability implications of three shrub species in the northern Apennines (Italy). Geomorphology 87:268-283. https://doi. org/10.1016/j.geomorph.2006.09.019

Ueda M, Shibata E (2001) Diurnal changes in branch diameter as indicator of water status of Hinoki cypress Chamaecyparis obtusa. Trees - Struct Funct 15:315-318. https://doi. org/10.1007/s004680100113 
Watson A, Marden M, Rowan D (1997) Root-wood strength deterioration in kanuka after clearfelling. $\mathrm{N} Z \mathrm{Z}$ For Sci 27: 205-215

Wu TH, McKinnell Iii WP, Swanston DN (1979) Strength of tree roots and landslides on price of Wales Island, Alaska. Can Geotech J 16:19-33

Yang Y, Chen L, Li N, Zhang Q (2016) Effect of root moisture content and diameter on root tensile properties. PLoS One 11(3):e0151791. https://doi.org/10.1371/journal. pone. 0151791
Yildiz A, Graf F, Rickli C, Springman SM (2018) Determination of the shearing behaviour of rootpermeated soils with a large-scale direct shear apparatus. CATENA 166:98-113. https://doi.org/10.1016/j. catena.2018.03.022

Zhang C-B, Chen L-H, Jiang J (2014) Why fine tree roots are stronger than thicker roots: the role of cellulose and lignin in relation to slope stability. Geomorphology 206:196-202. https://doi.org/10.1016/j. geomorph.2013.09.024 